\title{
Accounting for the Delay in the Transition from Acute to Chronic Pain: Axonal and Nuclear Mechanisms
}

\author{
Luiz F. Ferrari, Oliver Bogen, David B. Reichling, and 니on D. Levine \\ Departments of Medicine and Oral Surgery, and Division of Neuroscience, University of California, San Francisco, San Francisco, California 94143
}

Acute insults produce hyperalgesic priming, a neuroplastic change in nociceptors that markedly prolongs inflammatory mediatorinduced hyperalgesia. After an acute initiating insult, there is a $72 \mathrm{~h}$ delay to the onset of priming, for which the underlying mechanism is unknown. We hypothesized that the delay is due to the time required for a signal to travel from the peripheral terminal to the cell body followed by a return signal to the peripheral terminal. We report that when an inducer of hyperalgesic priming (monocyte chemotactic protein 1) is administered at the spinal cord of Sprague Dawley rats, priming is detected at the peripheral terminal with a delay significantly shorter than when applied peripherally. Spinally induced priming is detected not only when prostaglandin $\mathrm{E}_{2}\left(\mathrm{PGE}_{2}\right)$ is presented to the peripheral nociceptor terminals, but also when it is presented intrathecally to the central terminals in the spinal cord. Furthermore, when an inducer of priming is administered in the paw, priming can be detected in spinal cord (as prolonged hyperalgesia induced by intrathecal $\mathrm{PGE}_{2}$ ), but only when the mechanical stimulus is presented to the paw on the side where the priming inducer was administered. Both spinally and peripherally induced priming is prevented by intrathecal oligodeoxynucleotide antisense to the nuclear transcription factor CREB mRNA. Finally, the inhibitor of protein translation reversed hyperalgesic priming only when injected at the site where $\mathrm{PGE}_{2}$ was administered, suggesting that the signal transmitted from the cell body to the peripheral terminal is not a newly translated protein, but possibly a newly expressed mRNA.

\section{Introduction}

Hyperalgesic priming is a preclinical model of the transition from acute to chronic pain. It can be produced by inflammatory or neuropathic insults, and is expressed as a long-lasting prolongation in the response to low levels of hyperalgesic agents such as prostaglandin $\mathrm{E}_{2}\left(\mathrm{PGE}_{2}\right)$, adenosine, and serotonin, with normal nociceptive threshold in the absence of these agents (Aley et al., 2000; Parada et al., 2003a; Reichling and Levine, 2009). While in naive control rats $\mathrm{PGE}_{2}$-induced hyperalgesia is of short duration $(\sim 1 \mathrm{~h})$ and is dependent on stimulatory G-protein activation of protein kinase A (Aley and Levine, 1999), in the primed state $\mathrm{PGE}_{2}$-induced hyperalgesia is markedly prolonged, lasting $>24 \mathrm{~h}$ (Aley et al., 2000), with the prolongation phase ( $>1 \mathrm{~h}$ ) mediated by a signaling pathway involving an inhibitory G-protein, phospholipase $\mathrm{C} \beta 3$ and protein kinase $\mathrm{C} \varepsilon(\mathrm{PKC} \varepsilon$ ) (Aley et al., 2000; Parada et al., 2005; Joseph et al., 2007; Khasar et al., 2008; Dina et al., 2009; Reichling and Levine, 2009; Ferrari et al., 2013a). Importantly, the plasticity observed in hyperalgesic priming has been shown to be restricted to the nonpeptidergic, isolectin B4 (IB4)-positive nociceptors (Joseph and Levine, 2010), which ex-

Received Dec. 9, 2013; revised 0ct. 7, 2014; accepted Nov. 13, 2014.

Author contributions: L.F.F., 0.B., and J.D.L. designed research; L.F.F. performed research; L.F.F. analyzed data; L.F.F., D.B.R., and J.D.L. wrote the paper.

This study was funded by the National Institutes of Health.

The authors declare no competing financial interests.

Correspondence should be addressed to Dr. Jon D. Levine, University of California, San Francisco, 521 Parnassus Avenue, San Francisco, CA 94143-0440.E-mail: jon.levine@ucsf.edu.

DOI:10.1523/JNEUROSCI.5147-13.2015

Copyright $\odot 2015$ the authors $\quad 0270-6474 / 15 / 350495-13 \$ 15.00 / 0$ press the extracellular matrix molecule versican (Bogen et al., 2005).

The induction of priming is triggered by pronociceptive mediators that transiently activate the calcium independent novel $\varepsilon$ isoform of protein kinase C (PKC $\varepsilon$; Aley et al., 2000; Parada et al., 2003a) or molecules downstream of PKC $\varepsilon$ such as $\alpha$ calmodulindependent protein kinase II and the ryanodine receptor (Ferrari et al., 2013b). In turn, cytoplasmic polyadenylation elementbinding protein-dependent translation of mRNAs in the peripheral terminal of the nociceptor (Bogen et al., 2012; Ferrari et al., 2013c) contributes to the long-term maintenance of the primed state (Bogen et al., 2012; Ferrari et al., 2013c), which has been shown to persist unattenuated for at least 2 months (Aley et al., 2000; Parada et al., 2005).

A distinctive feature of hyperalgesic priming, whose underlying mechanism remains to be elucidated, is the very prolonged $(\sim 72 \mathrm{~h})$ delay from the acute painful event that induces priming, to the development of the long-lasting primed state (Bogen et al., 2012). In the present study, we explored the hypothesis that this delay is due, in part, to the time required for a signal to be generated in the peripheral terminal of the nociceptor and transported or transmitted to the cell body, where the regulation of transcription occurs, which, in turn, produces a signal that travels to the peripheral terminal of the nociceptor where hyperalgesic priming is expressed.

\section{Materials and Methods}

Animals. The experiments were performed on adult male Sprague Dawley rats (220-400 g; Charles River Laboratories). Animals were housed, three per cage, under a $12 \mathrm{~h}$ light/dark cycle in a temperature- and humidity-controlled room in the animal care facility of the University of 
A

(1)

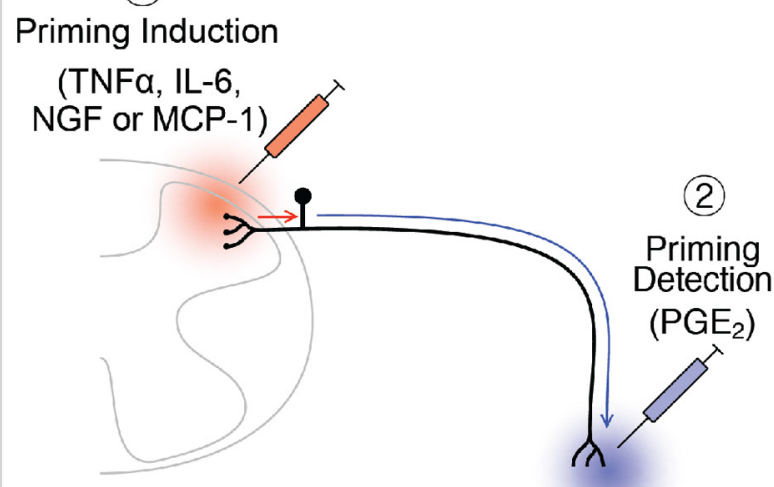

C

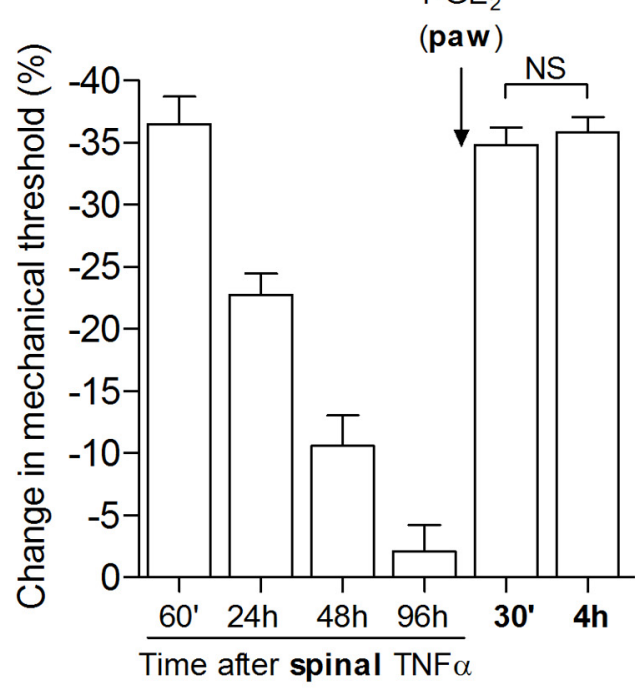

E

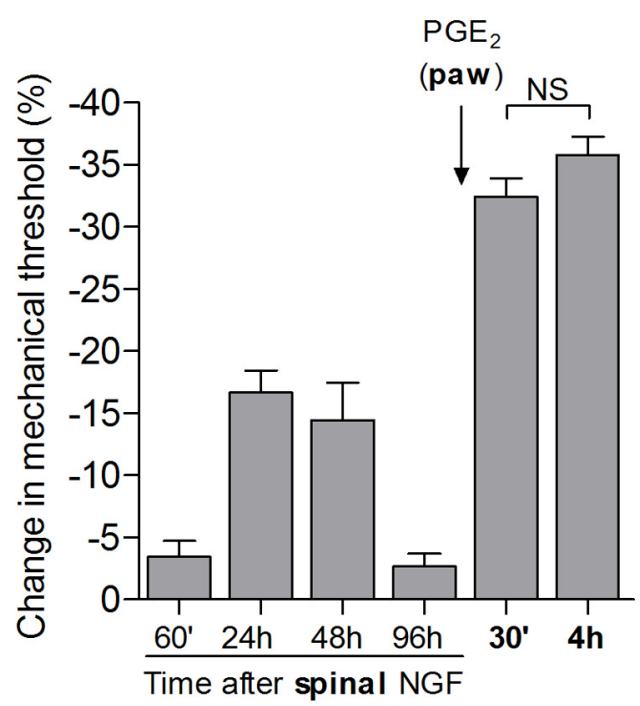

B

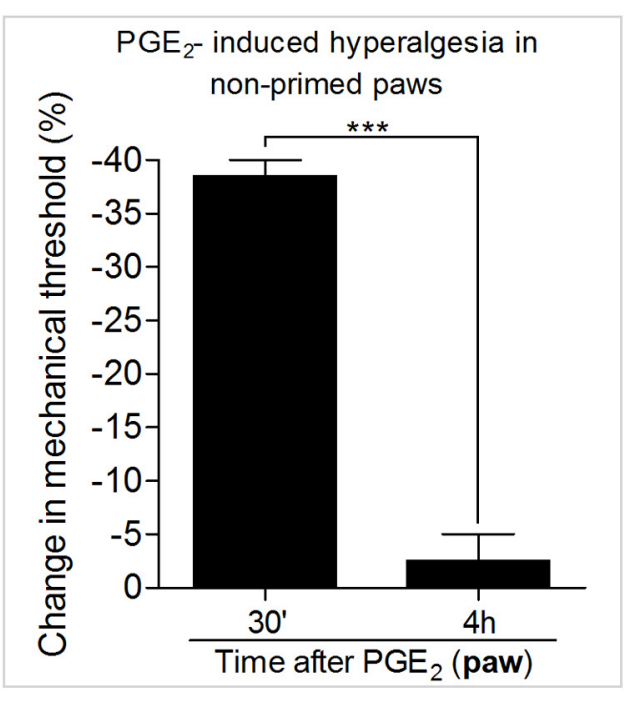

D

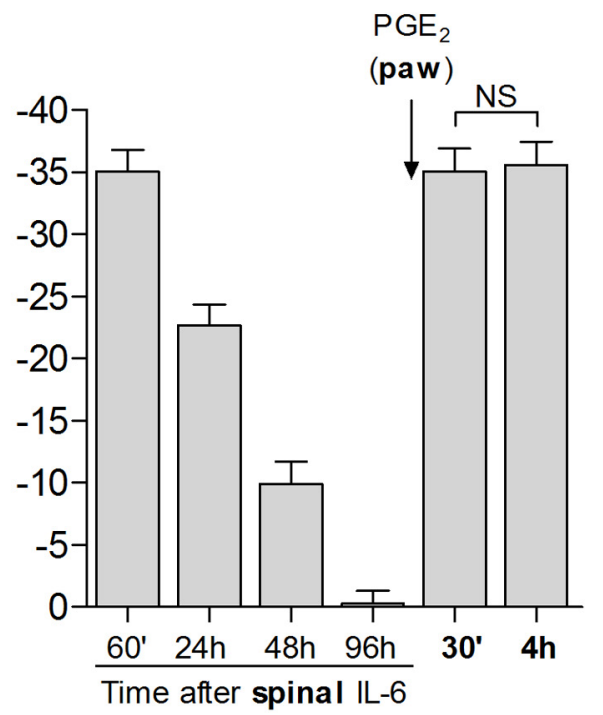

$\mathbf{F}$

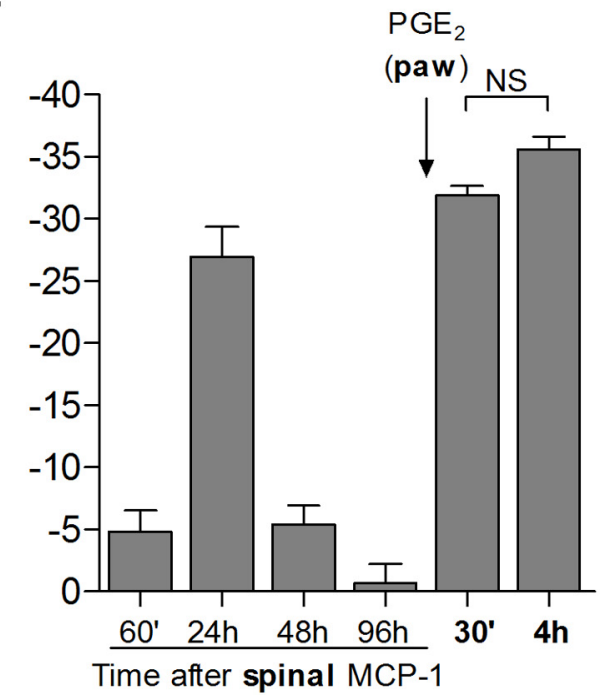

Figure 1. Spinal administration of TNF $\alpha, \mathrm{IL}-6, \mathrm{NGF}$, or MCP-1 induces hyperalgesic priming. Different groups of rats received a $20 \mu \mathrm{l}$ spinal injection of TNF $\alpha(\boldsymbol{C}, 20 \mathrm{ng} / \mu \mathrm{l})$, IL-6 (D, $1 \mathrm{ng} / \mu \mathrm{l}), \mathrm{NGF}$ $(\boldsymbol{E}, 150 \mathrm{ng} / \mu \mathrm{l})$, or MCP-1 $(\boldsymbol{F}, 20 \mathrm{ng} / \mu \mathrm{ll})$. All four mediators induced mechanical hyperalgesia. Ninety-six hours after injection, the mechanical nociceptive paw withdrawal threshold, evaluated by the Randall-Sellitto method, had returned to values not statistically different from preinjection values (paired Student's $t$ test). Average paw withdrawal threshold values before and $96 \mathrm{~h}$ after the spinal injections were as follows: $\operatorname{TNF} \alpha, 121.0 \pm 2.1$ and $118.3 \pm 2.2 \mathrm{~g}$, respectively $\left(t_{(5)}=1.061 ; p=0.3370\right) ; \mathrm{NGF}, 123.3 \pm 1.6$ and $120.0 \pm 1.5 \mathrm{~g}$, respectively (Figure legend continues.) 


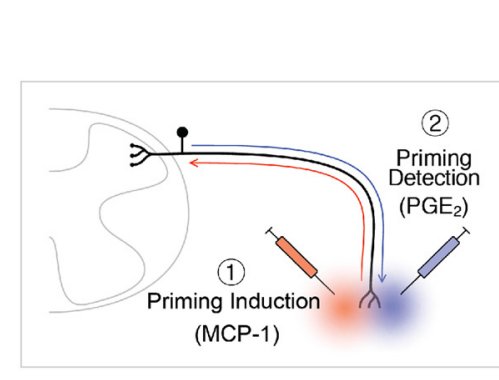

B

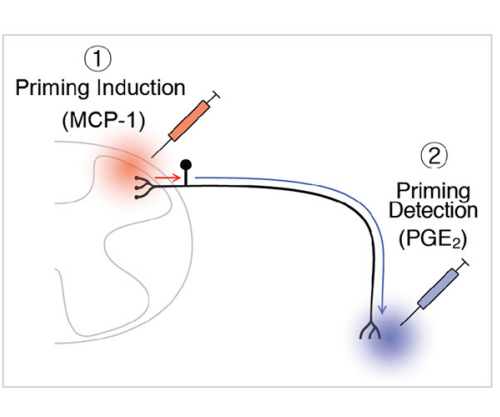

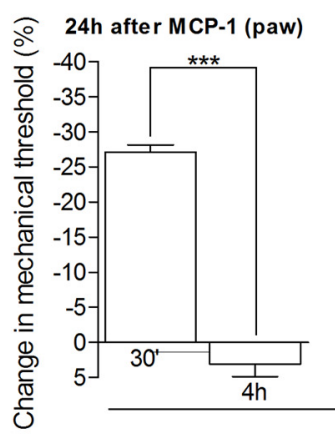
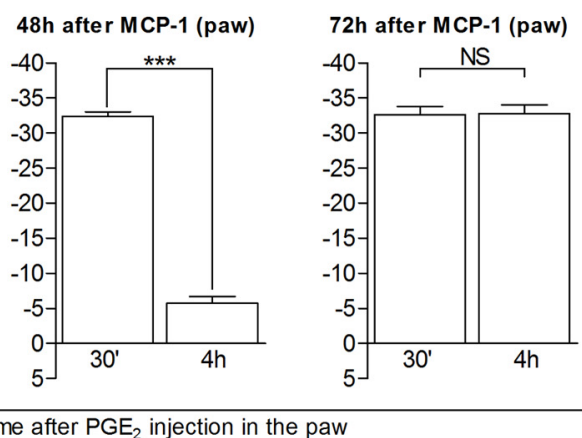

Time after $\mathrm{PGE}_{2}$ injection in the paw

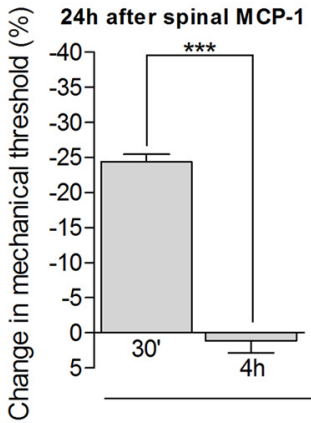

MCP-1 (spinal); $\mathrm{PGE}_{2}$ (paw)

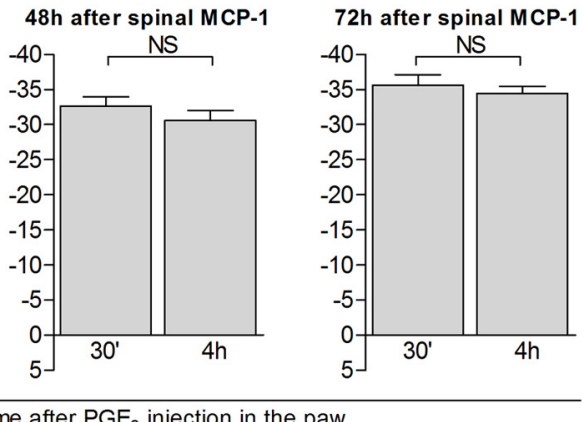

Time after $\mathrm{PGE}_{2}$ injection in the paw

Figure 2. Time course of development of hyperalgesic priming induced by intradermal (paw) or intrathecal spinal injection of MCP-1. Different groups of rats received injections of MCP-1 intradermally into the dorsum of the hindpaw ( $100 \mathrm{ng} ; \boldsymbol{A})$ or intrathecally in the spinal cord ( $20 \mathrm{ng} / \mu \mathrm{l}, 20 \mu \mathrm{l} ; \boldsymbol{B})$. $\mathrm{PGE}_{2}(100 \mathrm{ng})$ was injected into the dorsum of the hindpaw $24 \mathrm{~h}$ (left panels), $48 \mathrm{~h}$ (middle panels), or $72 \mathrm{~h}$ (right panels) later, and, the mechanical hyperalgesia, evaluated by the Randall-Selitto paw withdrawal test, $30 \mathrm{~min}$ and $4 \mathrm{~h}$ later. Average paw withdrawal thresholds before, and 24,48 , and $72 \mathrm{~h}$ after intradermal injection of MCP-1 (A) were as follows: $120.0 \pm 1.4$ and $107.5 \pm 1.8 \mathrm{~g}$, respectively (after $24 \mathrm{~h}, t_{(11)}=10.56 ; p<0.0001 ;$ paired Student's $t$ test); $119.6 \pm 1.4$ and $116.1 \pm 0.9 \mathrm{~g}$, respectively (after $48 \mathrm{~h}, t_{(11)}=2.782 ; p=0.1790, \mathrm{NS}$ ); and $118.6 \pm 1.1$ and $114.1 \pm 1.3 \mathrm{~g}$, respectively (after $72 \mathrm{~h}, t_{(11)}=2.279 ; p=0.4360, \mathrm{NS}$ ). For the groups treated with intrathecal injection of MCP-1 (B), the average paw withdrawal thresholds before, and 24,48 , and $72 \mathrm{~h}$ after injections were as follows: $120.1 \pm 1.5$ and $98.0 \pm 2.0 \mathrm{~g}$, respectively (after $24 \mathrm{~h}, t_{(11)}=8.071 ; p<0.0001 ;$ paired Student's $t$ test); $116.8 \pm 2.1$ and $110.5 \pm 1.2 \mathrm{~g}$, respectively (after $48 \mathrm{~h}, t_{(11)}=2.588 ; p=0.2502$, NS); and $120.3 \pm 1.5$ and $116.6 \pm 1.9 \mathrm{~g}$, respectively (after $72 \mathrm{~h}, t_{(11)}=1.910 ; p=0.0826$, NS). In the groups treated with MCP-1 into the dorsum of the hindpaw $(A)$, hyperalgesic priming was not established until $72 \mathrm{~h}\left[24\right.$ and $48 \mathrm{~h} \mathrm{panels:}{ }^{* * *} p<$ 0.0001 when comparing the $P G E_{2}$-induced hyperalgesia at $30 \mathrm{~min}$ and $4 \mathrm{~h} ; 72 \mathrm{~h}$ panel: $p=0.9404$ (NS); two-way repeated-measures ANOVA followed by Bonferroni post-test, $N=6$ rats (12 paws) per group]. On the other hand, in the group treated with spinal $M\left(P-1(B)\right.$, although the injection of $\mathrm{PGE}_{2}$ on the next day induced short-lasting hyperalgesia, it was no longer present at the fourth hour time point $\left({ }^{* * *} p<0.0001\right.$ when comparing both time points); when $\mathrm{PGE}_{2}$ was injected 48 or $72 \mathrm{~h}$ after spinal $\mathrm{MCP}-1$, the hyperalgesia remained statistically unattenuated at the fourth hour [NS in both cases: $48 \mathrm{~h}$ panel, $p=0.1864 ; 72 \mathrm{~h}$ panel, $p=0.3635$; two-way repeated-measures ANOVA followed by Bonferroni post-test, $N=6$ rats (12 paws) per group], demonstrating that hyperalgesic priming had already developed by $48 \mathrm{~h}$. Of note, since the hyperalgesia induced by MCP-1 was still significant $24 \mathrm{~h}$ after its administration $(\boldsymbol{A}$ and $\boldsymbol{B}$, both $p<0.0001$, paired Student's $t$ test), the baseline used to evaluate the effect induced by $\mathrm{PGE}_{2}$ at the 30 min time point was already decreased. For that reason, the change in the mechanical threshold induced by $\mathrm{PGE} 2$ injection appears smaller (left graphics). The schematic in $A$ shows the hypothetical pathway of a signal triggered by the injection of the priming agent MCP-1 (1, red syringe) in the peripheral terminal of the nociceptor (in the skin), directed to the cell body (red arrow), which induces changes in the peripheral terminal (blue arrow) detected by evaluating the hyperalgesia evoked by the injection of PGE (2, blue syringe). In $\boldsymbol{B}$, the signal that triggers hyperalgesic priming (1, red syringe) is spinal injection of MCP-1, and directed to the cell body (red arrow), from which the message for the neuroplastic change will spread (blue arrow) to the peripheral terminal (in skin) of the nociceptor, detected by the prolongation of the hyperalgesia evoked by injection of $\mathrm{PGE}_{2}$ in the paw (2, blue syringe).

$\leftarrow$

(Figure legend continued.) $\left(t_{(5)}=2.500 ; p=0.0545\right) ; \mathrm{lL}-6,123.3 \pm 1.7$ and $123.0 \pm 2.1 \mathrm{~g}$, respectively $\left(t_{(5)}=0.2548 ; p=0.8090\right) ;$ and $M(P-1,123.0 \pm 1.7 \mathrm{~g}$ and $121.3 \pm 2.0 \mathrm{~g}$, respectively $\left(t_{(11)}=1.131 ; p=0.2821\right)$. PGE $2(100 \mathrm{ng})$ was then injected intradermally into the dorsum of the hindpaw, and the mechanical threshold evaluated $30 \mathrm{~min}$ and $4 \mathrm{~h}$ later. In all cases, $\mathrm{PGE}_{2}$-induced hyperalgesia remained unatennuated at the fourth hour after injection [nonsignificant (NS) in all cases: $\boldsymbol{C}, p=0.6505 ; \boldsymbol{D}, p=0.7423 ; \boldsymbol{E}, p=0.1592 ; \boldsymbol{F}, p=0.1098$; two-way repeated-measures ANOVA followed by Bonferroni post-test], demonstrating the presence of hyperalgesic priming $(\boldsymbol{C}-\boldsymbol{E}, N=3$ rats, 6 paws per group; $\boldsymbol{F}, N=6$ rats, 12 paws per group). $A$, In the schematic, the red arrow represents the signal triggered by the spinal injection (1, red syringe) of the priming agents (TNF $\alpha, \mathrm{LL}-6, \mathrm{NGF}$, or MCP-1), in the central terminal of the nociceptor, directed to the cell body. A signal for the neuroplastic change then spreads to the peripheral terminal in the skin (blue arrow), where the presence of hyperalgesic priming can be detected by evaluating the hyperalgesia induced by the injection of $\mathrm{PGE}_{2}$ (2, blue syringe). $\boldsymbol{B}, \mathrm{In}$ control experiments, the hyperalgesia induced by $\mathrm{PGE}_{2}$ in naive rats (nonprimed), no longer present at the fourth hour after injection, is shown $\left(^{* * *} p<0.0001\right.$, when compared with the hyperalgesia at $30 \mathrm{~min}$ ).
California, San Francisco. Food and water were available ad libitum. All nociceptive testing was done between 10:00 A.M. and 5:00 P.M., and the experimental protocols were approved by the Institutional Animal Care and Use Committee at the University of California, San Francisco, and adhered to the National Institutes of Health Guidelines for the Care and Use of Laboratory Animals. A concerted effort was made to minimize the number of animals used and their suffering.

Testing mechanical nociceptive threshold. The mechanical nociceptive threshold was quantified using an Ugo Basile Analgesymeter (RandallSelitto paw-withdrawal test; Stoelting), a device that applies a linearly increasing mechanical force to the dorsum of the rat hindpaw, as previously described (Taiwo and Levine, 1989; Taiwo et al., 1989; Reichling and Levine, 2009). The nociceptive threshold was defined as the force, reported in grams, at which the rat withdrew its paw, and the baseline paw pressure threshold was defined as the mean of three readings taken before a test agent was administered; the response endpoint was an allor-none reaction (i.e., either the animal withdraws its paw from the stimulus or does not). Each paw was treated as an independent measure, and each experiment was performed on a separate group of rats. Nocice- 
ptive thresholds and experimental treatments were not performed blinded. Data are presented as the mean change from baseline mechanical nociceptive threshold.

Drugs and method of administration. The drugs used in this study were as follows: the direct-acting hyperalgesic inflammatory mediator $\mathrm{PGE}_{2}$, nerve growth factor (NGF), the protein translation inhibitor cordycepin from Cordyceps militaris, rat recombinant monocyte chemotactic protein 1 (MCP-1), and the adenosine deaminase inhibitor pentostatin, all from Sigma-Aldrich; the PKC $\varepsilon$-specific translocation inhibitor peptide $\mathrm{PKC} \varepsilon \mathrm{V}_{1-2}$, (PKC $\varepsilon$-I; Calbiochem), the PKC $\varepsilon$ activator $\psi \varepsilon$ RACK (Biomatik), rat recombinant interleukin-6 (IL-6; PeproTech), and rat recombinant tumor necrosis factor $\alpha$ (TNF $\alpha$; R\&D Systems). The selection of the drug doses was based on our previous studies (Taiwo et al., 1990; Ouseph et al., 1995; Khasar et al., 1999; Aley et al., 2000; Parada et al., 2005; Ferrari et al., 2013c).

Stock solutions of $\mathrm{PGE}_{2}$ in absolute ethanol $(1 \mu \mathrm{g} / \mu \mathrm{l})$ were further diluted in $0.9 \% \mathrm{NaCl}$ (1:50; final concentration, $0.02 \mu \mathrm{g} / \mu \mathrm{l}$ ) immediately before injection. The ethanol concentration of the final $\mathrm{PGE}_{2}$ solution was $\sim 2 \%$, and the injection volume was $5 \mu$ l. Stock solutions of cordycepin $(1 \mu \mathrm{g} / \mu \mathrm{l}$, dissolved in distilled water), prepared and further diluted in $0.9 \% \mathrm{NaCl}$, were used for intradermal injection into the dorsum of the hindpaw; for sys-

temic treatment with cordycepin, a dose of $5 \mathrm{mg} / \mathrm{kg}$, dissolved in distilled water, was administered intravenously in the tail vein. Because cordycepin is an adenosine analog that can be converted to an inactive metabolite by the enzyme adenosine deaminase (Tsai et al., 2010; Dalla Rosa et al., 2013), it must be administered with an adenosine deaminase inhibitor such as pentostatin (Johnston, 2011) to be effective (Koç and McCaffrey, 1995; Sugar and McCaffrey, 1998; Foss, 2000; Kodama et al., 2000; Yoshikawa et al., 2007). Pentostatin (1 mg/kg, dissolved in distilled water) was injected intravenously before cordycepin, in the same syringe, separated by an air bubble, to avoid mixing of the drugs. Control groups received vehicle or pentostatin plus vehicle. Before removal of the injection needle, administration of the drugs was followed by a bolus injection of an equal volume of saline solution.

Intradermal injections into the dorsum of the hindpaw were performed using a beveled 30 gauge hypodermic needle attached to a microsyringe by a short length of polyethylene (PE-10) tubing. The administration of cordycepin, $\mathrm{PKC} \varepsilon$-I, and $\psi \varepsilon$ RACK was preceded by distilled water $(2 \mu \mathrm{l}$ in the same syringe as the drug, separated by a bubble of air to avoid mixing) to induce hypotonic shock, which facilitates cell permeability to these membrane-impermeant agents (Borle and Snowdowne, 1982; Burch and Axelrod, 1987).

For intrathecal drug administration, rats were briefly anesthetized with $2.5 \%$ isoflurane (Phoenix Pharmaceuticals) in $95 \% \mathrm{O}_{2}$. Then, a 30 gauge hypodermic needle was inserted into the subarachnoid space, on the midline, between the L4 and L5 vertebrae, and the injection was performed $(20 \mu \mathrm{l})$. Animals regained consciousness $\sim 1$ min after the injection. Intrathecal injection was confirmed by a tail-flick reflex evoked by subarachnoid space access and bolus injection (Mestre et al., 1994).

Hyperalgesic priming. Hyperalgesic priming, a model of the transition from acute to chronic pain, was produced using a previously described procedure (Aley et al., 2000; Parada et al., 2003a; Reichling and Levine, 2009): to prime the sensory neuron, $\psi \varepsilon$ RACK was injected into the dorsum of the hindpaw, at the site of nociceptive testing. This induces mechanical hyperalgesia that resolves 3-5 d later, following which intradermal injection of $\mathrm{PGE}_{2}$ at the same site produces enhanced and prolonged mechanical hyperalgesia that lasts $>4 \mathrm{~h}$ and is still significant at $24 \mathrm{~h}$, as opposed to the effect of intradermal injection of $\mathrm{PGE}_{2}$ in a

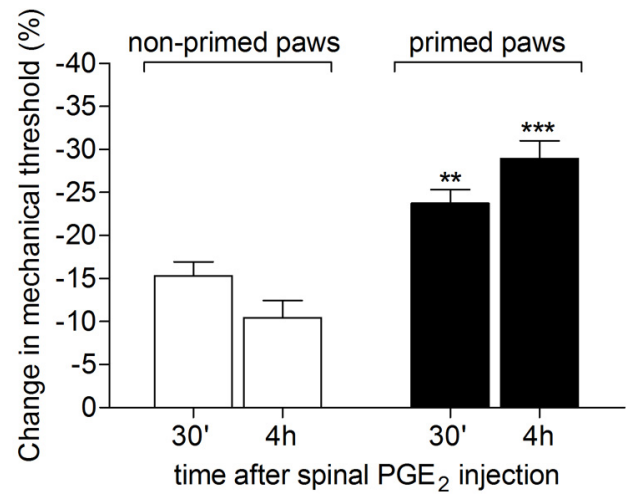

ming Induction

( $\psi \varepsilon R A C K)$

time after spinal $\mathrm{PGE}_{2}$ injection

Figure 3. Hyperalgesic priming can be detected at the spinal cord when it is induced at the hindpaw. Rats received intradermal injection of the PKC $\varepsilon$ activator $\psi \varepsilon$ RACK (1 $\mu \mathrm{g}$, black bars) into the dorsum of the right hindpaw. Vehicle (white bars) was injected We observed a statistically significant increase in the magnitude of the hyperalgesia induced by the injection of $\mathrm{PGE}_{2}$ in the (blue arrow), where the presence of hyperalgesic priming can be detected by evaluating the hyperalgesia evoked by intrathecal injection of $\mathrm{PGE}_{2}$ (2, blue syringe).

nonprimed paw, which lasts $\sim 1 \mathrm{~h}$. To induce priming at the spinal terminals of the primary afferent, we used intrathecal injection of TNF $\alpha$, IL-6, NGF, or MCP-1. That TNF $\alpha$, IL-6, and NGF induce priming when injected into the dorsum of the hindpaw has been shown previously (Parada et al., 2003b; Dina et al., 2008; Ferrari et al., 2010). MCP-1, which we have observed to induce priming after peripheral injection (Alvarez et al., 2014), was also included in the present experiments because it is a pronociceptive mediator that acts selectively on IB4-positive nociceptors (Bogen et al., 2009), the subtype of neurons shown to be involved in priming (Joseph and Levine, 2010). Thus, in the studies using spinal intrathecal drug administration, MCP-1 provides a more specific target, namely, the central terminals of those primary afferent nociceptors that mediate hyperalgesic priming (Joseph and Levine, 2010).

Oligodeoxynucleotide antisense to CREB $m R N A$. The oligodeoxynucleotide (ODN) antisense (AS) sequence for CREB mRNA, 5' -TGG TCA TCT AGT CAC CGG TG-3', synthesized by Invitrogen, was directed against a unique region of the rat mRNA sequence, which blocks the translation of both known isoforms of CREB (Widnell et al., 1996; LaneLadd et al., 1997; Ma et al., 2003). That this ODN AS sequence can be used to downregulate the expression of CREB has been shown previously (Widnell et al., 1996; Lane-Ladd et al., 1997; Ma et al., 2003). The ODN missense sequence $5^{\prime}$-GAC CTC AGG TAG TCG TCG TT-3' is a scramble of the AS sequence.

Before use, the ODNs were lyophilized and reconstituted in $0.9 \% \mathrm{NaCl}$ to a concentration of $2 \mu \mathrm{g} / \mu \mathrm{l}$. They were injected, as described above, by the spinal intrathecal route. A total of $40 \mu \mathrm{g}$ of ODN in a volume of $20 \mu \mathrm{l}$ was slowly injected. The use of the ODN AS sequence to manipulate the expression of proteins in nociceptors, important for their role in nociceptor sensitization, is well supported by previous studies by us (Parada et al., 2003a; Ferrari et al., 2010, 2012; Bogen et al., 2012) and others (Song et al., 2009; Su et al., 2011; Quanhong et al., 2012; Sun et al., 2013).

Statistics. In all experiments, the dependent variable was the paw withdrawal threshold, expressed as the percentage change from baseline. The average paw withdrawal thresholds before and after [ $4 \mathrm{~d}$ (experiments shown in Figs. 1, 3, 5, and 6), and 1 week (Fig. 4) or 2 weeks (Fig. 7) later, depending on the stimulus] the injection of the priming stimuli were 
A

(1)

Priming Induction

(TNFa, IL-6,

NGF or MCP-1)

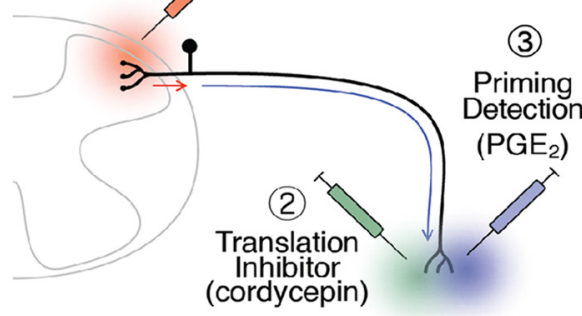

B

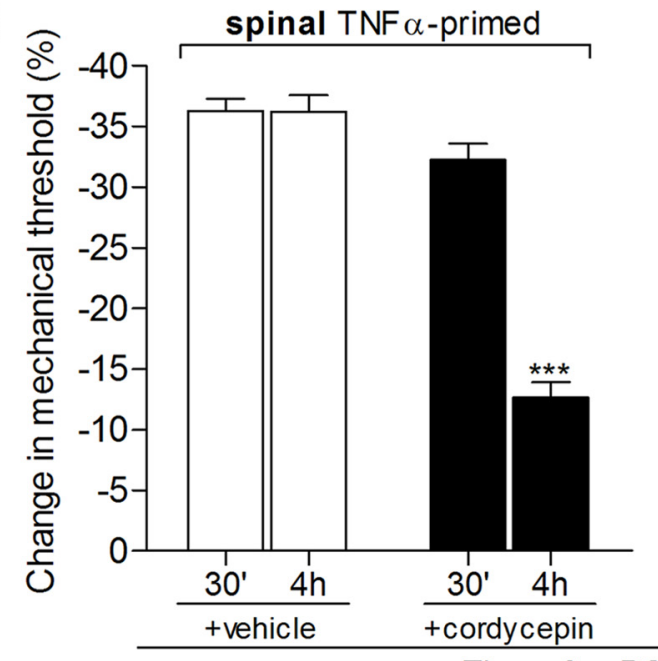

C

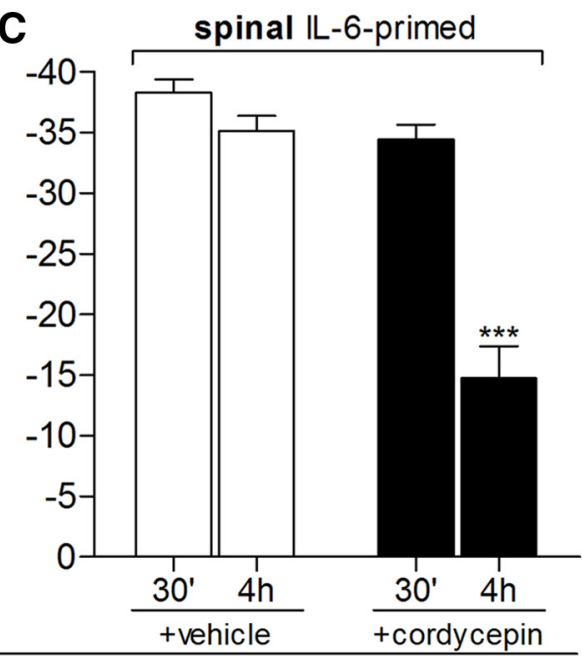

Time after $\mathrm{PGE}_{2}$ injection (paw)

D

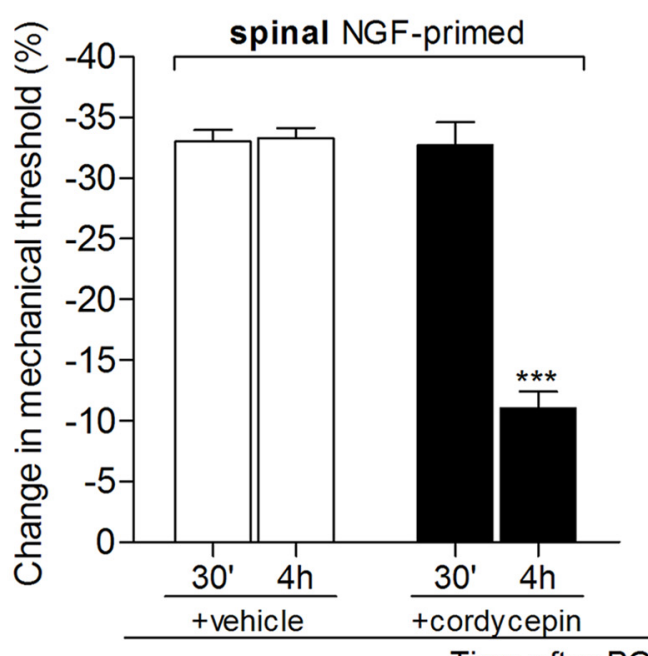

E

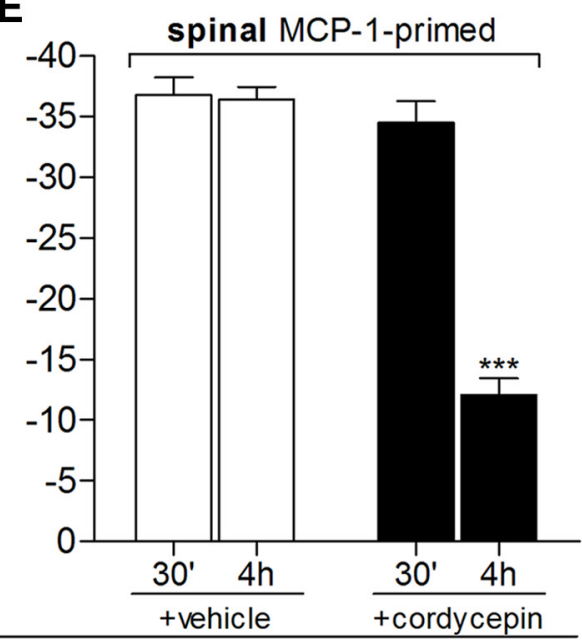

Time after $\mathrm{PGE}_{2}$ injection (paw)

Figure 4. Hyperalgesic priming at the central terminal of the nociceptor, in the spinal cord, depends on local protein translation. Rats that received spinal intrathecal injection of TNF $\alpha$ ( $\boldsymbol{B}, 20$ $\mathrm{ng} / \mu \mathrm{l}, 20 \mu \mathrm{l}), \mathrm{LL}-6(\boldsymbol{C}, 1 \mathrm{ng} / \mu \mathrm{l}, 20 \mu \mathrm{l}), \mathrm{NGF}(\boldsymbol{D}, 150 \mathrm{ng} / \mu \mathrm{l}, 20 \mu \mathrm{l})$, or MCP-1 $(\boldsymbol{E}, 20 \mathrm{ng} / \mu \mathrm{l}, 20 \mu \mathrm{l}) 1$ week before were tested for hyperalgesic priming of the response to PGE $2(100 \mathrm{ng})$ injected intradermally into the dorsum of the hindpaw, in the presence or absence of the protein translation inhibitor cordycepin ( $1 \mu \mathrm{g}$, injected at the same site as $\mathrm{PGE}_{2} 15$ min before). Average paw withdrawal thresholds before the intrathecal injections of the priming stimuli and before the injection of $\mathrm{PGE}_{2}$ (1 week later) were as follows: TNF $\alpha, 120.6 \pm 2.7$ and $119.0 \pm 2.2 \mathrm{~g}$, respectively, for the vehicle-treated group $\left(t_{(5)}=0.7734 ; p=0.4743, \mathrm{NS}\right)$ and $118.3 \pm 1.4$ and $118.3 \pm 2.0 \mathrm{~g}$, respectively, for the cordycepin-treated group $\left(t_{(5)}=0.000 ; p=1.000, \mathrm{NS}\right) ; \mathrm{IL}-6,120.6 \pm 1.8$ and $120.0 \pm 1.2 \mathrm{~g}$, respectively, for the vehicle-treated group $\left(t_{(5)}=0.3953 ; p=0.7089\right.$, NS) and $122.6 \pm 1.6$ and $121.3 \pm 2.9 \mathrm{~g}$, respectively, for the cordycepin-treated group $\left(t_{(5)}=0.0984\right.$; $p=0.5160, \mathrm{NS}) ; \mathrm{NGF}, 121.6 \pm 2.2$ and $119.6 \pm 1.4 \mathrm{~g}$, respectively, for the vehicle-treated group $\left(t_{(5)}=1.369 ; p=0.2292\right.$, NS) and $119.0 \pm 1.8$ and $118.6 \pm 0.8 \mathrm{~g}$, respectively, for the cordycepin-treated group $\left(t_{(5)}=0.1465 ; p=0.8893, \mathrm{NS}\right) ; \mathrm{MCP}-1,118.6 \pm 0.8$ and $117.3 \pm 1.2 \mathrm{~g}$, respectively, for the vehicle-treated group $\left(t_{(11)}=0.9834 ;\right.$ (Figure legend continues.) 
$119.1 \pm 0.5 \mathrm{~g}$ and $116.7 \pm 0.8 \mathrm{~g}$, respectively. The total number of rats used in this study was 231 (462 paws). The left and right hindpaws of the rats were used and considered as independent subjects. To demonstrate the lack of correlation between the outcomes from paws of the same rat (i.e., the independence between the left and right paws of the same animal), we assessed the correlation between the mechanical hyperalgesia produced by the injection of $\mathrm{PGE}_{2}$ into the dorsum of both hindpaws of a group of six rats (12 paws). The Pearson's correlation coefficient based on these six rats, which was only 0.064 , was not significantly different from zero, with a $p$ value of 0.904 , supporting the notion that the responses are independent. In addition, the analysis of the difference in the $\mathrm{PGE}_{2}$-induced hyperalgesia between the right and left paws of the same animal with a matched-pair $t$ test, which pays attention to the potential connection between the paws in the same animal, also found no significant difference in the mean scores between the paws, with a $p$ value of 0.696. Furthermore, the difference in the $\mathrm{PGE}_{2}$-induced hyperalgesia between the hindpaws was also examined with an independent-groups $t$ test that treated the left paws as a different independent group from the right paws. The results were identical to the matched-pair analysis, in that there was no difference in the mean scores between right and left paws ( $p=0.698$ ). Importantly, no statistically significant difference between paw withdrawal threshold absolute values (compared by paired Student's $t$ test) was observed between groups of rats subsequently injected with $\mathrm{PGE}_{2}$, vehicles, or inhibitors. In the experiments shown in Figure 2 $(N=36$ rats, 72 paws), to evaluate the change in the mechanical threshold induced by $\mathrm{PGE}_{2}$, the mechanical threshold evaluated immediately before $\mathrm{PGE}_{2}$ injection $(24,48$, or $72 \mathrm{~h}$ after injection of MCP-1) was considered the baseline threshold. To compare the percentage change in the hyperalgesia induced by injection of $\mathrm{PGE}_{2}$ in different groups, twoway repeated-measures ANOVA, followed by Bonferroni post-test, was performed. Prism version 5.0 (GraphPad Software) was used to plot the graphics and to perform the statistical analysis; $p<0.05$ was considered statistically significant. Data are presented as the mean \pm SEM.

\section{Results}

\section{Inducing priming by stimulating the central terminal of the nociceptor}

Given the marked difference in the length of the central and peripheral branches of nociceptors innervating the hindpaw, we tested whether the delay to onset of the primed state would be shorter if the agent that induces priming was administered to the central branch in the spinal cord. Pronociceptive mediators (TNF $\alpha$, IL-6, NGF, and MCP-1) that induce priming when administered in peripheral tissue were injected intrathecally into the spinal cord in separate groups of rats. That TNF $\alpha$, IL- 6 , and NGF induce priming when injected into the dorsum of the hindpaw has been shown previously (Parada et al., 2003b; Dina et al., 2008; Ferrari et al., 2010). MCP-1, which we have observed to

\footnotetext{
$\leftarrow$

(Figure legend continued.) $p=0.3466, \mathrm{NS}$ ) and $120.6 \pm 1.0$ and $119.6 \pm 0.9 \mathrm{~g}$, respectively, for the cordycepin-treated group $\left(t_{(11)}=0.9199 ; p=0.3774\right.$, NS); paired Student's $t$ test showed no significant difference between these two values. The nociceptive mechanical paw withdrawal threshold was evaluated $30 \mathrm{~min}$ and $4 \mathrm{~h}$ after $\mathrm{PGE}_{2}$ injection. Two-way repeatedmeasures ANOVA followed by Bonferroni post-test showed significant attenuation of $\mathrm{PGE}_{2}-$ induced hyperalgesia at the fourth hour after injection in the groups pretreated with cordycepin $\left({ }^{* * *} p<0.001\right.$ in all cases, when vehicle- and cordycepin-treated groups are compared at the fourth hour; $\boldsymbol{B}, F_{(1,10)}=126.19 ; \boldsymbol{C}, F_{(1,10)}=53.36 ; \boldsymbol{D}, F_{(1,10)}=60.63 ; \boldsymbol{E}, F_{(1,22)}=63.07 ; p<$ 0.0001 for all cases, when vehicle and cordycepin groups are compared), indicating a role of local protein translation in hyperalgesic priming induced by spinal injection of TNF $\alpha, \mathrm{IL}-6, \mathrm{NGF}$, or MCP-1 [N $=3$ rats ( 6 paws, $\boldsymbol{B}-\boldsymbol{D})$ or $N=6$ rats (12 paws, $\boldsymbol{E}$ ) per group]. $\boldsymbol{A}$, In the schematic, the red arrow represents the signal triggered by the spinal injection (red syringe) of the priming agents (1, TNF $\alpha, \mathrm{LL}-6, \mathrm{NGF}$, and MCP-1) originating in the central terminal of the nociceptor and the subsequent signal (blue arrow) to the peripheral nociceptor terminal (in skin) where hyperalgesic priming is detected by the prolongation of hyperalgesia evoked by $\mathrm{PGE}_{2}$ injected in the paw (2, blue syringe). The green syringe represents the site where cordycepin (or vehicle) was injected.
}

induce priming after peripheral injection (Alvarez et al., 2014), was also included in the present experiment because it is a pronociceptive mediator that acts on IB4-positive, but not IB4negative, nociceptors (Bogen et al., 2009). To address the role of the cell body in hyperalgesic priming, we first tested whether administration of the inducers of hyperalgesic priming intrathecally in the spinal cord can induce hyperalgesic priming in the paw at the peripheral terminal of the nociceptor. As shown in Figure 1, intrathecal injection of each agent induced peripheral hyperalgesic priming, manifested as prolongation of mechanical hyperalgesia induced by $\mathrm{PGE}_{2}$ injected in the paw (measured $4 \mathrm{~h}$ after the injection of $\mathrm{PGE}_{2}$, a time at which $\mathrm{PGE}_{2}$-induced hyperalgesia would be fully resolved in a naive rat; Aley and Levine, 1999). Importantly, although the mechanical hyperalgesia induced by the injection of these agents had different time courses (Fig. 1C-F, first four bars), we waited $96 \mathrm{~h}$ (when the mechanical thresholds in all groups had returned to baseline values) to test for the presence of priming (Fig. $1 C-F$, two bars on the right). The choice of $96 \mathrm{~h}$ is based on the observation that the establishment of priming takes $\sim 72 \mathrm{~h}$ after injection of the priming stimulus (Bogen et al., 2012). However, as seen in Figure 2, we have further observed that the delay to the induction of priming was $\sim 48 \mathrm{~h}$ when the inducer was injected intrathecally into the spinal cord (compared with $\sim 72 \mathrm{~h}$ when the inducing agent was injected into the paw).

\section{Induction of hyperalgesic priming in the paw also induces priming at the central terminal of the nociceptor}

Following administration of inducers of hyperalgesic priming into the paw, hyperalgesic priming in the spinal cord was detected as a prolongation of mechanical hyperalgesia induced by $\mathrm{PGE}_{2}$ injected intrathecally (Fig. 3). Of note, the intrathecal injection of $\mathrm{PGE}_{2}$ in nonprimed rats, in a concentration similar to the dose injected into the dorsum of the hindpaw $(20 \mathrm{ng} / \mu \mathrm{l})$, but diluted by the larger volume of the CSF, induced less intense hyperalgesia when compared with the hyperalgesia induced by the injection of $\mathrm{PGE}_{2}$ into the paw. We observed that, similar to the hyperalgesia induced by injection of $\mathrm{PGE}_{2}$ into the paw of primed rats, the hyperalgesia induced by the intrathecally injected $\mathrm{PGE}_{2}$ was significantly prolonged.

We have shown previously that hyperalgesic priming in the paw is reversed when protein translation is inhibited locally in the paw (Ferrari et al., 2013c). Hyperalgesic priming induced in the spinal cord is also mediated by a similar mechanism, since the administration of the translation inhibitor cordycepin in the same site in the paw as $\mathrm{PGE}_{2}$, in rats previously primed by intrathecal injection of TNF $\alpha$, IL-6, NGF, or MCP-1, significantly attenuated hyperalgesic priming (Fig. 4). Consistent with a need for only local protein translation, spinal administration of a translation inhibitor did not affect the prolonged response to $\mathrm{PGE}_{2}$ injected in the paw (Fig. 5A). Similarly, a translation inhibitor administered in the paw had no effect on the prolonged hyperalgesia induced by intrathecally injected $\mathrm{PGE}_{2}$ (Fig. $5 B$ ).

Thus, agents that induce priming when administered to the peripheral terminal of the nociceptor also induce priming at the central terminal, suggesting that signals initiated at either the central or peripheral terminal of a nociceptor induce the neuroplastic changes that underlie hyperalgesic priming throughout the axon branches of the sensory neuron (where ongoing local protein translation is critical to maintain the primed state). 


\section{A PRIMING DETECTED IN THE PAW}

priming induced by $\psi \varepsilon$ RACK in the paw

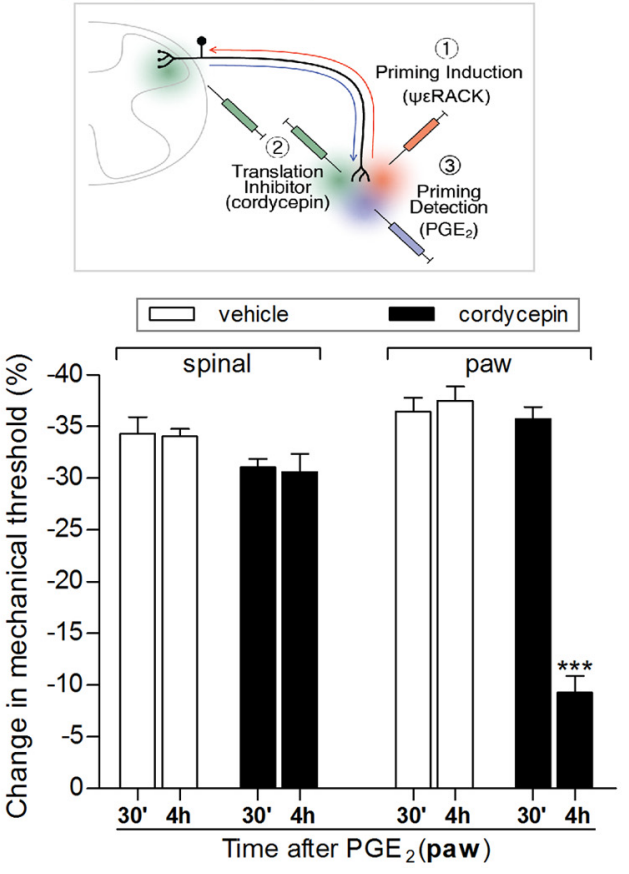

B PRIMING DETECTED IN THE SPINAL CORD

priming induced by $\psi \varepsilon$ RACK in the paw

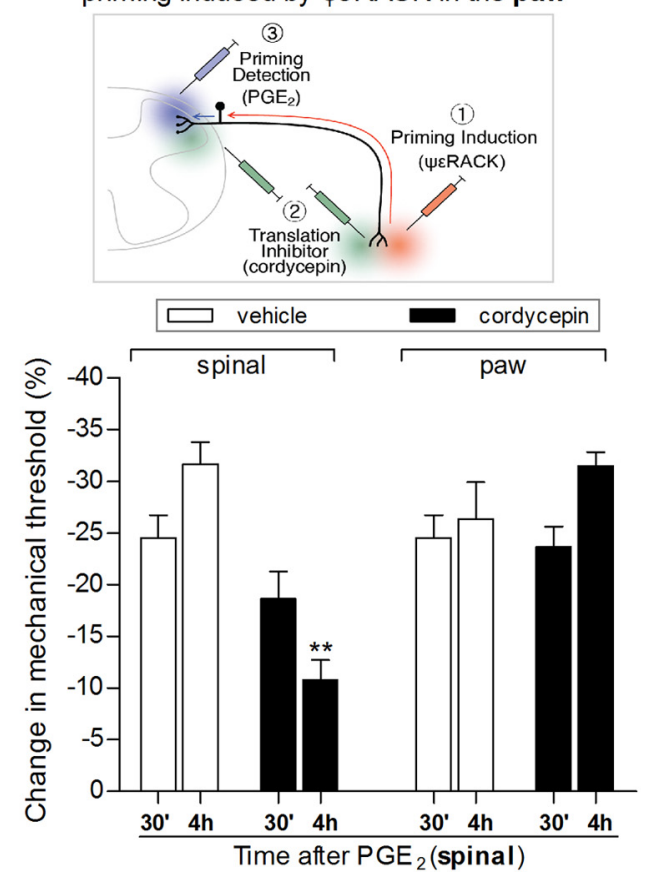

priming induced by MCP-1 in the spinal cord

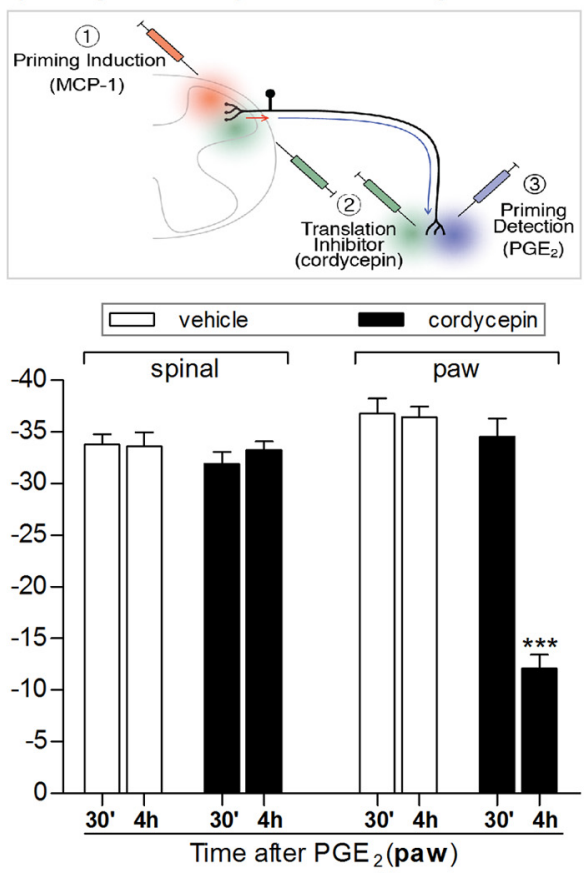

priming induced by MCP-1 in the spinal cord

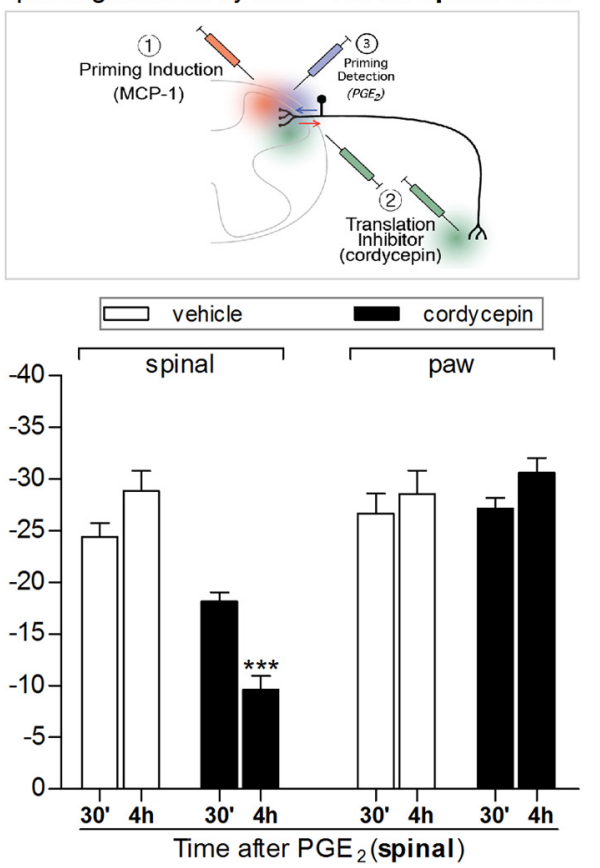

Figure 5. Inhibition of protein translation only reverses priming at the terminal where it is administered. Rats received intradermal injection of the PKC $\varepsilon$ activator $\psi \varepsilon$ RACK ( $1 \mu \mathrm{g})$ into the dorsum of the hindpaw (lefts panels) or spinal intrathecal injection of MCP-1 $(20 \mathrm{ng} / \mu \mathrm{l}, 20 \mu \mathrm{l}$; right panels). No significant difference between the mechanical thresholds before and $4 \mathrm{~d}$ after the injections (when the experiments were performed) was observed (paired Student's $t$ test, data not shown); the average paw withdrawal thresholds before and $4 \mathrm{~d}$ after injection of $\psi \varepsilon$ RACK (left panels) were $119.9 \pm 0.8$ and $119.6 \pm 0.7 \mathrm{~g}$, respectively $\left(t_{(47)}=0.5329 ; p=0.5966, \mathrm{NS}\right)$. For the rats treated with intrathecal injection of MCP 1 (right panels), the average paw withdrawal thresholds before and $4 \mathrm{~d}$ after injection were $116.7 \pm 0.6$ and $116.7 \pm 0.7 \mathrm{~g}$, respectively $\left(t_{(95)}=0.07275 ; p=0.9422\right.$, NS). Rats were then divided into groups, vehicle (white bars) or the protein translation inhibitor cordycepin (black bars), which were administered intrathecally to the spinal cord $(200 \mathrm{ng} / \mu \mathrm{l}, 20 \mu \mathrm{l})$ or injected into the hindpaw $(1 \mu \mathrm{g})$. Fifteen minutes later, $\mathrm{PGE}_{2}$ was injected into the dorsum of the hindpaw $(100 \mathrm{ng}, A)$ or into the spinal cord $(20 \mathrm{ng} / \mu \mathrm{l}, 20 \mu \mathrm{l}, \boldsymbol{B})$, and the paw withdrawal thresholds were evaluated 30 min and $4 \mathrm{~h} \mathrm{later}$. Importantly, cordycepin alone did not affect the mechanical paw withdrawal threshold. However, when it was injected at the same site as $\mathrm{PGE}_{2}$, the PGE -induced hyperalgesia was significantly attenuated at the $4 \mathrm{~h}$ time point $\left(\boldsymbol{A}\right.$, left: $F_{(1,10)}=129.42,{ }^{* * *} p<0.001 ; A$, right: $F_{(1,22)}=63.07$, ${ }^{* * *} p<0.001 ; B$, left: $F_{(1,10)}=28.58,{ }^{* *} p=0.0003 ; B$, right: $F_{(1,22)}=51.52,{ }^{* * *} p<0.001$, when the hyperalgesia at 30 min and $4 \mathrm{~h}$ are compared, two-way repeated-measures ANOVA followed by Bonferroni post-test). In contrast, when cordycepin was administered at the opposite terminal of the nociceptor from the terminal at which the nociceptive testing was performed, the prolonged PGE 2 -induced hyperalgesia was not reduced $[p>0.05$ in all cases, when comparing vehicle- and cordycepin-treated groups; $N=3$ rats ( 6 paws, $\psi \varepsilon$ RACK treated) or $N=6$ rats (12 paws, MCP-1-treated) per group]. 


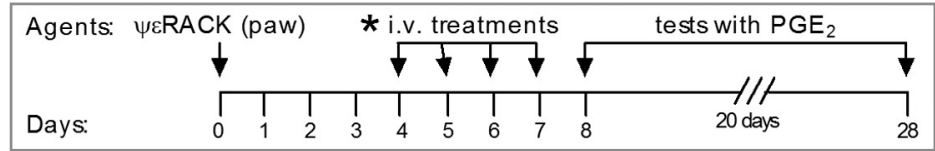

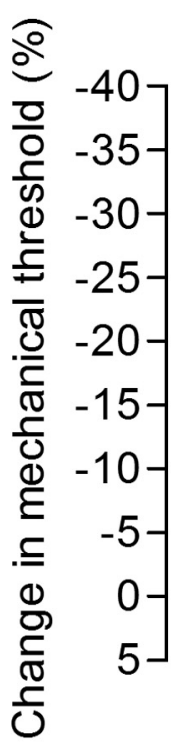

B

$$
\begin{gathered}
\text { * vehicles group } \\
\text { (control) }
\end{gathered}
$$

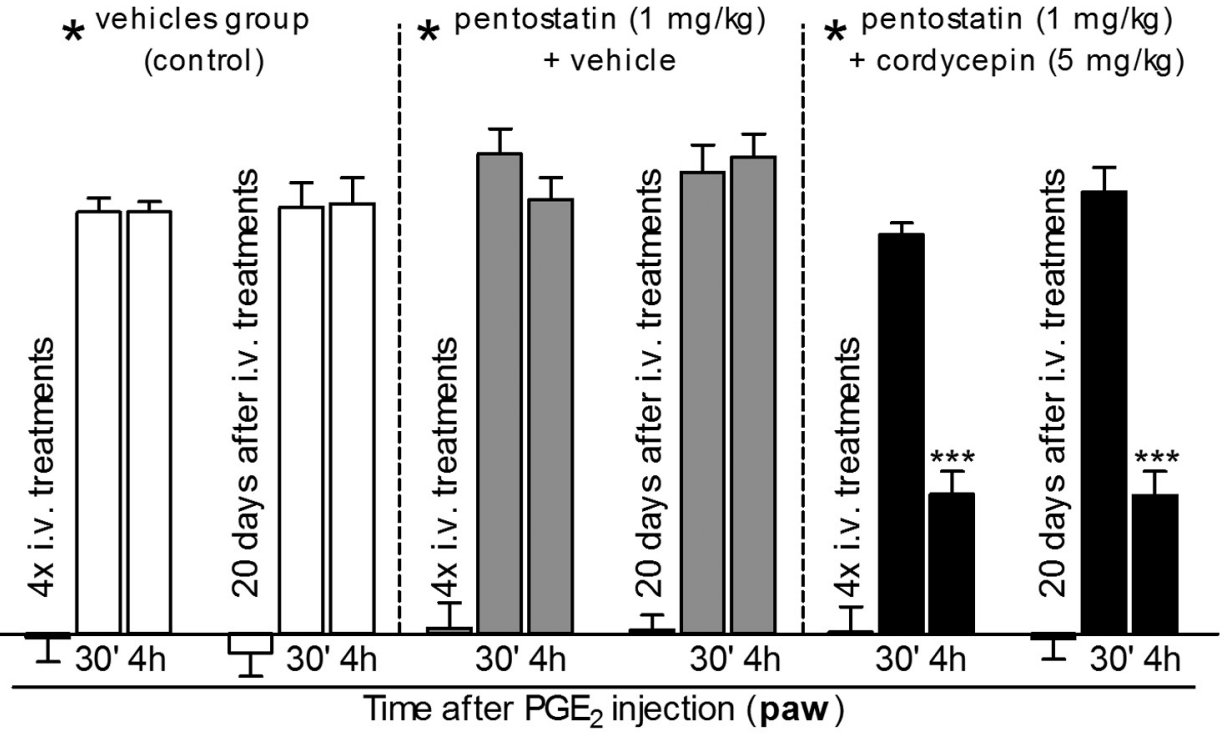

priming induced by MCP-1 in the spinal cord

Agents: MCP-1 (spinal)

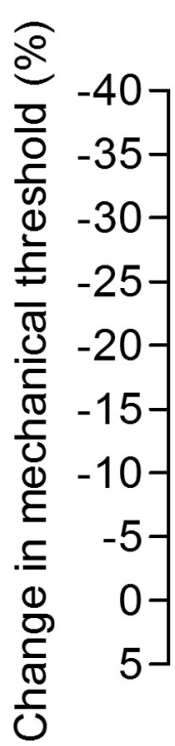

$*^{\text {vehicles group }}$ $\quad *^{\text {pentostatin }(1 \mathrm{mg} / \mathrm{kg})}$

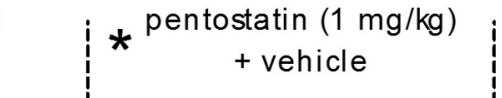

pentostatin $(1 \mathrm{mg} / \mathrm{kg})$ + cordycepin $(5 \mathrm{mg} / \mathrm{kg})$

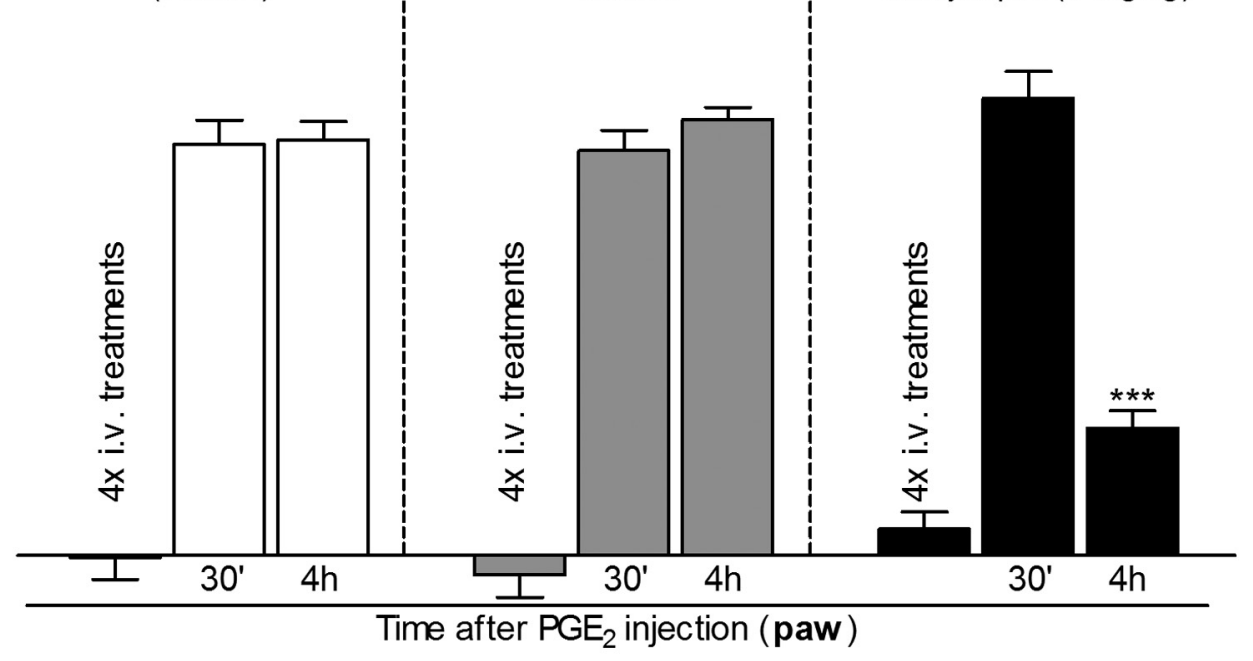

Figure 6. Systemic treatment with protein translation inhibitor reverses hyperalgesic priming in both the paw and spinal cord. Hyperalgesic priming was induced by intradermal injection of the PKC $\varepsilon$ activator $\psi \varepsilon$ RACK $(1 \mu \mathrm{g})$ in the paw $(\boldsymbol{A})$ or by spinal injection of MCP-1 $(20 \mathrm{ng} / \mu \mathrm{l}, 20 \mu \mathrm{l} ; \boldsymbol{B})$. Four days later, as indicated by * in the schematics on the top of the figures, when the mechanical nociceptive paw withdrawal thresholds had returned to baseline values (data not shown), different groups of rats received intravenous vehicles (control groups, white bars), pentostatin (1 $\mathrm{mg} / \mathrm{kg}$ ) plus vehicle (gray bars), or pentostatin plus cordycepin ( $5 \mathrm{mg} / \mathrm{kg}$, black bars), for 4 consecutive days. On the fifth day, $\mathrm{PGE}_{2}(100 \mathrm{ng})$ was injected into the dorsum of the hindpaw, and the mechanical nociceptive paw withdrawal thresholds were evaluated $30 \mathrm{~min}$ and $4 \mathrm{~h}$ later. There were no significant differences in the average paw withdrawal thresholds before the injection of $\mathrm{PGE}_{2}$ when compared with the thresholds before the injections of the priming stimuli (paired Student's $t$ test): $A$ : vehicle-plus-vehicle group, $111.6 \pm 1.6$ and $112.3 \pm 1.7 \mathrm{~g}$, respectively $\left(t_{(5)}=0.2454 ; p=\right.$ 0.8159 , NS); pentostatin-plus-vehicle group, $108.3 \pm 3.0$ and $111.6 \pm 0.9 \mathrm{~g}$, respectively $\left(t_{(5)}=1.300 ; p=0.2504\right.$, NS); cordycepin-plus-pentostatin group, $120.0 \pm 2.5$ and $118.0 \pm 2.0 \mathrm{~g}$, respectively $\left(t_{(5)}=0.7746 ; p=0.4736, \mathrm{NS}\right) ; \boldsymbol{B}$ : vehicle-plus-vehicle group, $117.6 \pm 2.6$ and $114.3 \pm 2.0 \mathrm{~g}$, respectively $\left(t_{(5)}=1.976 ; p=0.1051\right.$, NS); (Figure legend continues.) 


\section{Systemic administration of a translation inhibitor reverses central and peripheral priming}

Since systemically active translation inhibitors have been developed for clinical use to treat cancer (Behbakht et al., 2011; Demetri et al., 2013; Ma et al., 2013; Maj-Hes et al., 2013; Ogawa et al., 2013), we tested the hypothesis that systemic administration of such drugs would reverse priming both at the central and peripheral terminal of the nociceptor (Fig. 6). Systemic administration of cordycepin ( $5 \mathrm{mg} / \mathrm{kg}$; and pentostatin, $1 \mathrm{mg} / \mathrm{kg}$, daily intravenous administration for 4 consecutive days, before testing on the fifth day) significantly attenuated hyperalgesic priming measured as the prolongation of the hyperalgesia induced by $\mathrm{PGE}_{2}$ challenge in the paw [which was induced by administration of $\psi \varepsilon$ RACK $(1 \mu \mathrm{g}$, Fig. $6 A)$ in the paw or MCP-1 $(20 \mathrm{ng} / \mu \mathrm{l} ; 20 \mu \mathrm{l}$, Fig. $6 B)$ in the spinal cord], indicating that systemic treatment with protein translation inhibitors can be effective to reverse chronic pain syndromes where hyperalgesic priming plays a role.

\section{Nuclear mechanism in priming}

Finally, we tested the hypothesis that the signal traveling along the axon of the sensory neuron from the central or peripheral terminal toward the cell body, required to induce priming at both terminals, engages CREB, a nuclear transcription factor implicated in neuroplasticity. CREB is a cellular transcription factor that binds to nuclear DNA sequences to increase or decrease the transcription of many genes (Mayr and Montminy, 2001), and CREB-related changes in gene expression in the neuronal nucleus have been implicated in long-term sensitization and neuronal regeneration (Herdegen et al., 1992; Fields et al., 1997; Teng and Tang, 2006). We tested the hypothesis that CREB plays a role in the induction, but not necessarily the maintenance, of hyperalgesic priming. In support of this hypothesis, we found that intrathecal administration of an ODN antisense to CREB mRNA prevented (but did not reverse) priming induced either by activation of $\mathrm{PKC} \varepsilon$ in the paw or by intrathecal injection of MCP-1

\footnotetext{
$\leftarrow$

(Figure legend continued.) pentostatin-plus-vehicle group, $111.6 \pm 1.6$ and $111.0 \pm 1.3 \mathrm{~g}$, respectively $\left(t_{(5)}=0.5976 ; p=0.5761, \mathrm{NS}\right)$; cordycepin-plus-pentostatin group, $113.3 \pm 2.1$ and $112.0 \pm 1.0 \mathrm{~g}$, respectively $\left(t_{(5)}=0.7906 ; p=0.4650, \mathrm{NS}\right)$. Of note, the systemic treatment with the vehicles, pentostatin, or cordycepin (or the combinations), after priming was induced ( $4 \mathrm{~d}$ after injection of $\psi \varepsilon$ RACK or MCP-1) did not induce significant changes on the mechanical thresholds: $A$ : vehicle-plus-vehicle group, $t_{(5)}=1.118 ; p=0.3144$, NS; pentostatin-plus-vehicle group, $t_{(5)}=0.4152 ; p=0.6452$, NS; cordycepin-plus-pentostatin group, $t_{(5)}=0.1395 ; p=0.8945, \mathrm{NS} ; \boldsymbol{B}$, vehicle-plus-vehicle group, $t_{(5)}=1.400 ; p=0.2204$, NS; pentostatin-plus-vehicle group, $t_{(5)}=2.739 ; p=0.4090$, NS; cordycepin-plus-pentostatin group, $t_{(5)}=0.6523 ; p=0.5430$, NS. Two-way repeated-measures ANOVA followed by Bonferroni post-test showed that in the groups treated with cordycepin plus pentostatin, but not in the controls (vehicles or pentostatin plus vehicle), the hyperalgesia induced by $\mathrm{PGE}_{2}$ was significantly attenuated at the fourth hour $\left[A:{ }^{* * *} p<0.001\right.$, when the $\mathrm{PGE}_{2}$-induced hyperalgesia at the $4 \mathrm{~h}$ time point in the cordycepin-plus-pentostatin group is compared with the control groups: cordycepin-plus-pentostatin $\times$ vehicles group: $F_{(1,50)}=62.66, p<0.0001$; cordycepin-plus-pentostatin $\times$ pentostatin-plus-vehicle groups: $F_{(1,50)}=58.22, p<0.0001$; nonsignificant $\left(F_{(1,50)}=\right.$ $6.45, p>0.05)$ difference was observed between vehicles $\times$ pentostatin-plus-vehicle groups; $\boldsymbol{B}$ : ${ }^{* * *} p<0.001$, when the $\mathrm{PGE}_{2}$-induced hyperalgesia at the $4 \mathrm{~h}$ time point in the cordycepinplus-pentostatin is compared with the control groups: cordycepin-plus-pentostatin $\times$ vehicles group: $F_{(1,20)}=16.30, p=0.0024$; cordycepin-plus-pentostatin $\times$ pentostatin-plus-vehicle groups: $F_{(1,20)}=22.67, p=0.0008$; nonsignificant difference $\left(F_{(1,20)}=0.01, p=0.9394\right)$ was observed between vehicles $X$ pentostatin-plus-vehicle groups], showing reversal of the $\psi \varepsilon$ RACK- and MCP-1-induced hyperalgesic priming by systemic treatment with cordycepin. In addition, when tested for priming again by intradermal injection of $\mathrm{PGE}_{2} 20 \mathrm{~d}$ later, the hyperalgesia at the fourth hour was still attenuated in the groups previously treated with cordycepin plus pentostatin $\left(\boldsymbol{A},{ }^{* * *} p<0.001\right.$, when compared with the control groups), showing that the reversal of priming was very long lasting $[N=3$ rats (6 paws) per group].
}

(Fig. 7). The ODN missense control had no significant effect. In Figure 8, the proposed axonal and nuclear mechanisms underlying hyperalgesic priming are illustrated.

\section{Discussion}

\section{The delay to induction of hyperalgesic priming}

The $72 \mathrm{~h}$ delay in the induction of hyperalgesic priming has been an unexplained feature of this phenomenon. However, since other forms of long-term neuronal plasticity involve changes of gene expression (Lee et al., 2008; Knöll and Nordheim, 2009; Bengtson and Bading, 2012; Kim et al., 2013), we hypothesized that this could play a role in priming, and that the time required for a signal to be carried by the sensory axon from the nerve ending to the nucleus, transcription in the cell body, and a return signal from the nucleus to the peripheral nerve ending followed by peripheral translation (Ferrari et al., 2013c) contribute to this delay. We found that intrathecal administration of a pronociceptive mediator that induces priming when administered at the peripheral terminal, induces priming in the central terminal of the nociceptor (Fig. 1), with a markedly shorter latency to onset (Fig. 2), implicating axoplasmic transport of a signaling molecule from the nerve terminal to the cell body. Since some part of the delay to onset of the primed state is due to nuclear and peripheral translation mechanisms, which adds an unknown additional delay, and the molecule transmitted to the cell body is likely different from the one transmitted from the cell body back to the terminal, we are not yet in a position to implicate a specific mechanism for the relevant signals to move between the terminals and the cell body.

\section{Hyperalgesic priming at the central terminal of the primary afferent neuron}

The observation that hyperalgesic priming in the paw can be induced by the administration of inducing agents in the spinal cord raised the possibility that priming might also be expressed in the spinal cord as an increase in the response to inflammatory mediators at the central terminal of the primary afferent. Consistent with hyperalgesic priming occurring at the central terminal, we found that intradermal as well as intrathecal administration of priming stimuli caused a prolongation of mechanical hyperalgesia induced by intrathecally administered $\mathrm{PGE}_{2}$. While the prolonged hyperalgesia induced by peripheral administration of $\mathrm{PGE}_{2}$ is mediated by sensitization of the nociceptor (Aley et al., 2000; Parada et al., 2005; Reichling and Levine, 2009), the mechanism for prolongation of mechanical hyperalgesia induced by intrathecal $\mathrm{PGE}_{2}$ is currently unknown. Because $\mathrm{PGE}_{2}$ can enhance neurotransmitter release (Osaka, 2008; Fehrenbacher et al., 2009; Ma, 2010; Anneken et al., 2013; Lindgren et al., 2013), one possibility is enhanced neurotransmitter release from the central terminal of the nociceptor. A contribution from postsynaptic mechanisms cannot, however, be excluded since prostaglandins also have effects on neurons in the CNS (Hori et al., 2000; Sang and Chen, 2006; Ohinata and Yoshikawa, 2008; O’Banion, 2010).

\section{Trans-terminal priming suggests participation of the sensory neuron cell body}

We hypothesized that the induction of priming involves a retrograde signal from the cell body back to nerve endings. The observation that hyperalgesic priming can also be expressed at the central terminal of the nociceptor, when priming was induced by an agent administered at the peripheral terminal, raised the possibility that the retrograde priming signal sent from the cell body to the peripheral terminal might also travel along the central 
A
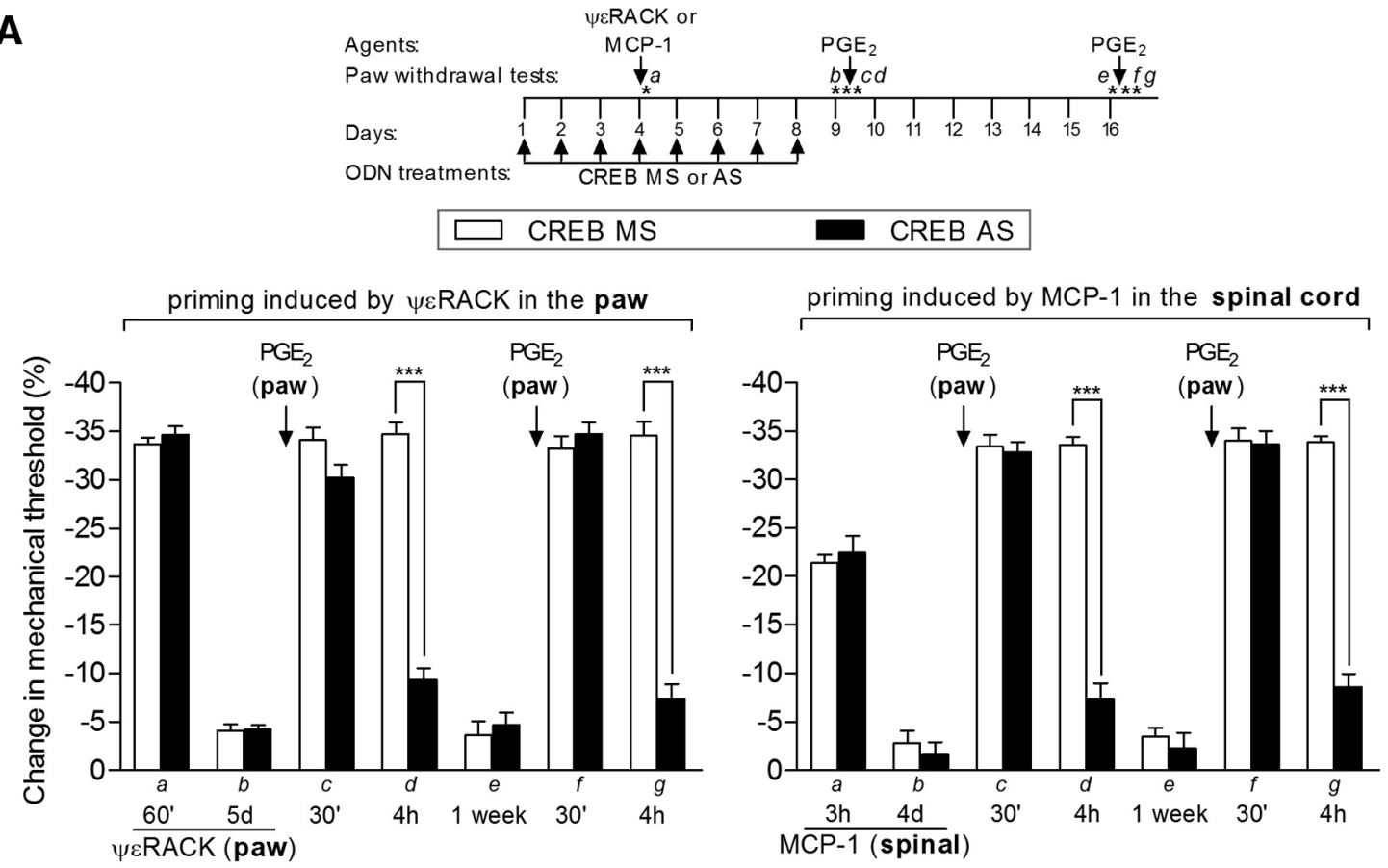

B
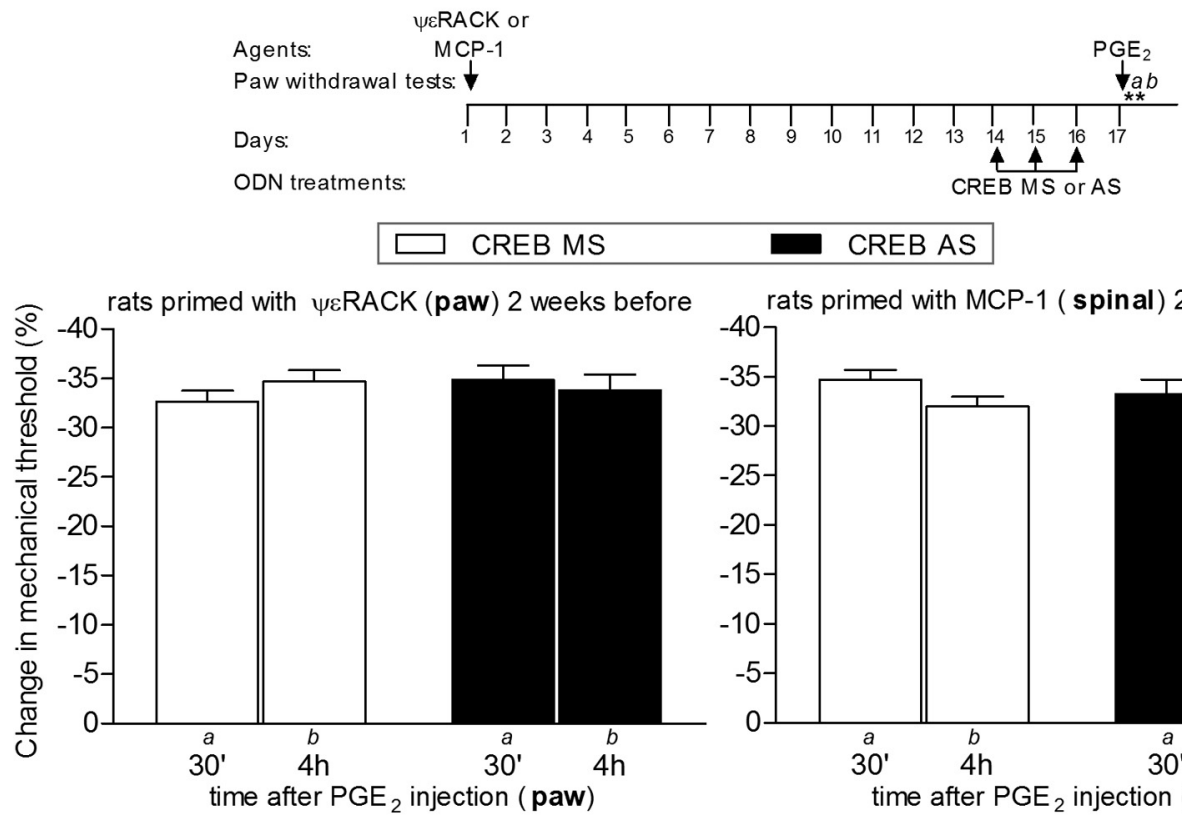

CREB AS

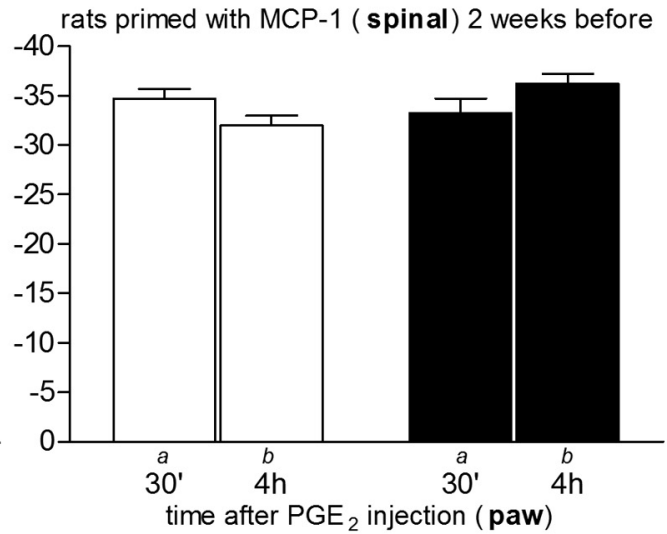

Figure 7. Knockdown of CREB prevents $(\boldsymbol{A})$, but does not reverse $(\boldsymbol{B})$, hyperalgesic priming. $\boldsymbol{A}$, Rats were treated with daily spinal intrathecal injections of ODN AS (black bars) for CREB mRNA, for 3 consecutive days, to decrease its levels in the sensory neuron and prevent its activation by the priming inducers $\psi \varepsilon R A C K$ ( $1 \mu \mathrm{g}$, injected intradermally into the dorsum of the hindpaws; $A$, left) or MCP-1 (20 ng/ $\mu \mathrm{l} ; 20 \mu \mathrm{l}$, injected by the intrathecal route; $A$, right), injected on the fourth day. Control animals were treated, following the same protocol, with missense (MS; white bars). To prevent further activation of a signaling pathway that will ultimately produce priming during the acute effect of $\psi \varepsilon R A C K$ or MCP-1, the ODN treatments continued until the return of the mechanical nociceptive paw withdrawal thresholds to baseline values, when hyperalgesic priming was assessed by the administration of $\mathrm{PGE}_{2}(100 \mathrm{ng})$. $\mathrm{PGE}_{2}$ was injected intradermally into the dorsum of the hindpaw, and the mechanical threshold was evaluated $30 \mathrm{~min}$ and $4 \mathrm{~h}$ later. Average paw withdrawal thresholds before the injections of the priming stimuli and before the injection of $\mathrm{PGE}_{2}(8 \mathrm{~d}$ later) were as follows: $\psi \varepsilon$ RACK in the paw, left, $121.3 \pm 1.9$ and $121.9 \pm 1.4 \mathrm{~g}$, respectively, for the (REB MS-treated group $\left(t_{(11)}=0.000 ; p=1.0000\right.$, NS), and $125.9 \pm 1.7$ and $125.5 \pm 1.1 \mathrm{~g}$, respectively, for the AS-treated group $\left(t_{(11)}=0.1461 ; p=0.8864, \mathrm{NS}\right) ; \mathrm{MCP}-1$, intrathecally, right, $123.3 \pm 2.5$ and $120.5 \pm 1.7 \mathrm{~g}$, respectively, for the MS-treated group $\left(t_{(11)}=1.787 ; p=\right.$ $0.1014, \mathrm{NS})$ and $120.6 \pm 2.3$ and $116.5 \pm 1.4 \mathrm{~g}$, respectively, for the AS-treated group $\left(t_{(11)}=1.948 ; p=0.0773\right.$, NS). Paired Student's $t$ test showed no significant difference between these two values. Two-way repeated-measures ANOVA followed by Bonferroni post-test showed significant mechanical hyperalgesia induced by PGE $_{2} 30$ min after the injection. However, while in the MS-treated groups the magnitude of $\mathrm{PGE}_{2}$ hyperalgesia was still significant at the fourth hour, in the AS-treated groups it was strongly attenuated in both the $\psi \varepsilon$ RACK- and the MCP-1-primed group $\left({ }^{* * *} p<0.001\right.$ when the MS- and the AS-treated groups are compared). When tested again for priming with PGE 1 week after the last treatment with ODN AS or MS, a time point when the levels of CREB had returned to pre-AS levels, the prolongation of PGE -induced hyperalgesia was still attenuated (at the $4 \mathrm{~h}$ time point) in the ODN AS-treated groups, but not in the MS-treated groups, indicating a role of CREB in the induction of hyperalgesic priming ${ }^{* * *} p<0.001$ when the MS- and the AS-treated groups are compared; $A, N=6$ rats (12 paws) per group]. 0 f note, no difference in the mechanical thresholds was observed at this time point, when compared with pre-priming stimuli thresholds: $\psi \varepsilon R A C K$, left, $t_{(11)}=0.8710 ; p=0.4024$ (NS) for the CREB MS-treated group, and $t_{(11)}=1.497 ; p=0.1624$ (NS) for the AS-treated group; MCP-1, right, $t_{(11)}=2.482 ; p=0.305$ (NS) for the MS-treated group, and $t_{(11)}=1.915 ; p=0.0819$ (NS) for the AS-treated group (paired Student's $t$ test). $\boldsymbol{B}$, Rats that were treated with intradermal injection of the PKC $\varepsilon$ activator $\psi \varepsilon$ RACK (1 $\mu \mathrm{g})$ into the dorsum of the hindpaw (B, left) or (Figure legend continues.) 


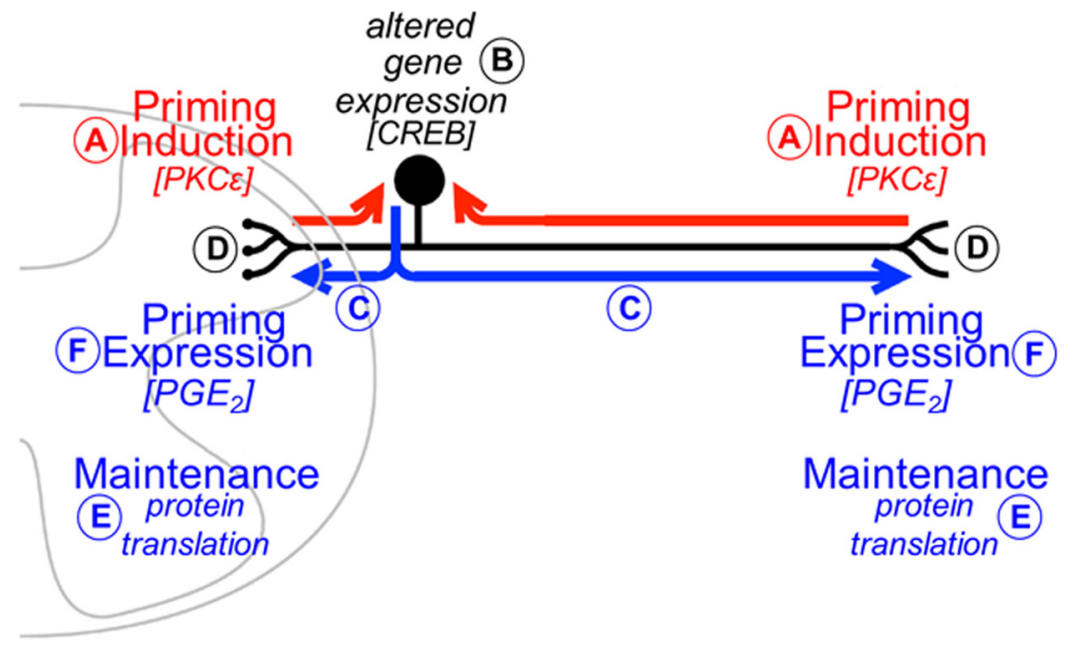

Figure 8. Schematic of the proposed axonal and nuclear mechanisms underlying hyperalgesic priming. Our experiments support the hypothesis that an inflammatory event that activates PKC $\varepsilon$ in nonpeptidergic nociceptors $(\boldsymbol{A})$ triggers gene transcription in the cell body that is dependent on CREB ( $\boldsymbol{B}$, red arrows). The resultant mRNA species will then be transported to the terminals of the nociceptor ( $\boldsymbol{C}$, blue arrows), where translation mechanisms will take place $(\boldsymbol{D})$ and, as a consequence, produce hyperalgesic priming. This phenomenon will then be maintained, independently of CREB, by local protein translation at the central and peripheral terminals of the nociceptor $(\boldsymbol{E})$. The time for the development of priming will depend on the transport of the newly formed mRNA to the peripheral or central terminals of the nociceptor. $\boldsymbol{F}$, The expression of this neuroplasticity, an increased response to pronociceptive inflammatory cytokines, can be verified by the prolongation of the mechanical hyperalgesia induced by the injection of $\mathrm{PGE}_{2}(\boldsymbol{F})$.

branch of the axon to induce priming at the spinal terminal. Therefore, we tested whether mediators that produce hyperalgesic priming of the nociceptor peripheral terminal, when injected at the peripheral terminal, also induce priming of the peripheral terminal when injected intrathecally to the central terminal. We found that intrathecal injection of these mediators produces hyperalgesic priming, a prolonged response to $\mathrm{PGE}_{2}$ injected into the paw. We also found that injection of an inducing agent into the paw caused hyperalgesic priming at the central terminal. Furthermore, as predicted by the hypothesis that the delay in the induction of priming is dependent on axon length, the latency to the onset of the primed state in both cases was markedly shortened (Devor, 1999). This might explain the distinct time course for priming establishment, depending on the site where the inducer is administered, since the neuroplastic change observed in primed nociceptors is dependent on the transport of nuclear transcripted mRNAs to the terminals where they will be translated (Ferrari et al., 2013c). Moreover, the transmission of the

$\leftarrow$

(Figure legend continued.) spinal intrathecal injection of MCP-1 (20 ng/ $\mu \mathrm{l}, 20 \mu \mathrm{l} ; \boldsymbol{B}$, right) 2 weeks before were treated with ODN AS (black bars) for CREB mRNA for 3 consecutive days to decrease the levels of CREB in the nociceptor. Control animals were treated, following the same protocol, with MS (white bars). On the fourth day, $\mathrm{PGE}_{2}(100 \mathrm{ng})$ was injected intradermally into the dorsum of the hindpaws, and the mechanical thresholds were evaluated $30 \mathrm{~min}$ and $4 \mathrm{~h}$ later. Average paw withdrawal thresholds before the injections of $\psi \varepsilon$ RACK or MCP- 1 and before the injection of $\mathrm{PGE}_{2}$ were as follows: $\psi \varepsilon R A C K$, left, $121.6 \pm 2.7$ and $123.3 \pm 1.6 \mathrm{~g}$, respectively, for the CREB MS-treated group ( $\left.t_{(11)}=0.8752 ; p=0.4002, \mathrm{NS}\right)$, and $113.3 \pm 1.8$ and $112.6 \pm 2.1 \mathrm{~g}$, respectively, for the AS-treated group $\left(t_{(11)}=0.4838 ; p=0.6380, \mathrm{NS}\right)$; MCP-1, right, $114.1 \pm 1.4$ and $114.6 \pm 1.2 \mathrm{~g}$, respectively, for the MS-treated group $\left(t_{(11)}=\right.$ $0.2536 ; p=0.8045, \mathrm{NS}$ ) and $117.5 \pm 1.7$ and $117.5 \pm 1.4 \mathrm{~g}$, respectively, for the AS-treated group $\left(t_{(11)}=0.0000 ; p=1.0000\right.$, NS). Paired Student's $t$ test showed no significant difference between these two values. Two-way repeated-measures ANOVA followed by Bonferroni posttest showed no difference in the magnitude of the $P \mathrm{PE}_{2}$-induced hyperalgesia at $30 \mathrm{~min}$ and $4 \mathrm{~h}$ in both the ODN AS- and MS-treated groups (rats primed with $\psi \varepsilon$ RACK: $F_{(1,22)}=1.47, p=$ 0.2378 ; rats primed with $M\left(P-1: F_{(1,22)}=1.39, p=0.2511\right)$, indicating that (REB does not play a role in the maintenance of hyperalgesic priming $[\boldsymbol{B}: N=6$ rats (12 paws) per group]. priming signal between the two branches of the sensory nerve axon on the central and peripheral sides of the cell body suggested that mechanisms in the dorsal root ganglion (DRG) could play a crucial role in the induction of priming. However, this finding alone cannot rule out the possibility of a direct transmission of a signal from one branch of the bipolar axon to another, without any involvement of the cell body.

\section{A nuclear mechanism in hyperalgesic priming}

To begin to address the question of whether the signal transmitted from the nociceptor terminals along the length of the axon involves a nuclear event in the cell body, we administered an ODN antisense to CREB mRNA (Widnell et al., 1996; Lane-Ladd et al., 1997; Ma et al., 2003), a nuclear transcription factor (Montminy et al., 1990; Montminy, 1997; Shaywitz and Greenberg, 1999) that plays a role in the neuroplasticity of learning and memory (Montminy et al., 1990; Montminy, 1997; Shaywitz and Greenberg, 1999; Kandel, 2012). CREB antisense prevented priming, which is compatible with a role of a nuclear transcription mechanism. CREB antisense, however, did not reverse priming, suggesting that CREB-dependent patterns of gene expression in the nucleus play a critical role in its induction, but is not necessary to maintain the primed state. Therefore, processes that maintain hyperalgesic priming may be entirely localized in the nerve ending, consistent with our previous finding that peripheral administration of a protein translation inhibitor can reverse established hyperalgesic priming.

While the precise mechanism by which CREB contributes to hyperalgesic priming is currently unknown, its function in the DRG neuron has been extensively studied. We have previously shown that repeated administration of the $\mu$-opioid receptor agonist morphine at the peripheral terminal of the nociceptor induces hyperalgesic priming (Joseph et al., 2010), and, while it has yet to be shown that intrathecal opioids induce priming, they are well established to produce analgesia by action at the central terminal of the nociceptor. Of note in this regard, Ma et al. (2001) have shown that repeated morphine exposure increased the number of DRG neurons expressing phosphorylated extracellular signal-regulated protein kinase, also implicated in hyperalgesic priming (Dina et al., 2003; Ferrari et al., 2014), as well as those expressing phosphorylated CREB (pCREB; Ma et al., 2001). In neurons that are selectively deficient in axonal CREB transcripts, increases in nuclear pCREB, CRE-mediated transcription, and neuronal survival elicited by axonal application of NGF (which also produces hyperalgesic priming; Ferrari et al., 2010) are abolished, indicating a signaling function for axon-synthesized CREB (Cox et al., 2008). Furthermore, IL-6, which also produces hyperalgesic priming, engages a similar signaling pathway (Eyre and Baune, 2012; Yang et al., 2012; Chou et al., 2013). Of note, protein synthesis inhibitors prevent NGF-induced maintenance of axonal CREB, implying that NGF promotes the translation of CREB mRNA in the axon (Cox et al., 2008). Exactly how this contrib- 
utes to the induction of hyperalgesic priming remains to be established.

\section{Cordycepin}

An ultimate goal in studying the mechanism of hyperalgesic priming is to create a foundation for novel treatments of chronic pain. In most cases, such treatments would be used after the condition is already established. This study has shown that hyperalgesic priming is maintained independent of the nucleus, by protein translation occurring in both nerve endings (Ferrari et al., 2013 b,c), suggesting that a successful clinical intervention would optimally target both sites. Cordycepin is a clinically approved protein translation inhibitor that is systemically administered and appears to cross the blood-brain barrier (Rottenberg et al., 2005). Our demonstration that systemic cordycepin administration can reverse priming produced by stimuli in both the spinal cord and periphery is a preliminary indication that this drug might be useful as a treatment for chronic pain. Our findings that cordycepin attenuated priming only when injected at the same site where $\mathrm{PGE}_{2}$ was administered (Fig. 5), and that the induction, but not maintenance, of priming, depends on CREBactivated nuclear transcription (Fig. 6) suggest that the signal transmitted to the terminals of the nociceptor is not a newly translated protein, but possibly a newly expressed mRNA.

\section{References}

Aley KO, Levine JD (1999) Role of protein kinase A in the maintenance of inflammatory pain. J Neurosci 19:2181-2186. Medline

Aley KO, Messing RO, Mochly-Rosen D, Levine JD (2000) Chronic hypersensitivity for inflammatory nociceptor sensitization mediated by the epsilon isozyme of protein kinase C. J Neurosci 20:4680-4685. Medline

Alvarez P, Green PG, Levine JD (2014) Role for monocyte chemoattractant protein-1 in the induction of chronic muscle pain in the rat. Pain 155: 1161-1167. CrossRef Medline

Anneken JH, Cunningham JI, Collins SA, Yamamoto BK, Gudelsky GA (2013) MDMA increases glutamate release and reduces parvalbuminpositive GABAergic cells in the dorsal hippocampus of the rat: role of cyclooxygenase. J Neuroimmune Pharmacol 8:58-65. CrossRef Medline

Behbakht K, Sill MW, Darcy KM, Rubin SC, Mannel RS, Waggoner S, Schilder RJ, Cai KQ, Godwin AK, Alpaugh RK (2011) Phase II trial of the mTOR inhibitor, temsirolimus and evaluation of circulating tumor cells and tumor biomarkers in persistent and recurrent epithelial ovarian and primary peritoneal malignancies: a Gynecologic Oncology Group study. Gynecol Oncol 123:19-26. CrossRef Medline

Bengtson CP, Bading H (2012) Nuclear calcium signaling. Adv Exp Med Biol 970:377-405. CrossRef Medline

Bogen O, Dreger M, Gillen C, Schröder W, Hucho F (2005) Identification of versican as an isolectin B4-binding glycoprotein from mammalian spinal cord tissue. FEBS J 272:1090-1102. CrossRef Medline

Bogen O, Dina OA, Gear RW, Levine JD (2009) Dependence of monocyte chemoattractant protein 1 induced hyperalgesia on the isolectin B4binding protein versican. Neuroscience 159:780-786. CrossRef Medline

Bogen O, Alessandri-Haber N, Chu C, Gear RW, Levine JD (2012) Generation of a pain memory in the primary afferent nociceptor triggered by PKC $\varepsilon$ activation of CPEB. J Neurosci 32:2018-2026. CrossRef Medline

Borle AB, Snowdowne KW (1982) Measurement of intracellular free calcium in monkey kidney cells with aequorin. Science 217:252-254. CrossRef Medline

Burch RM, Axelrod J (1987) Dissociation of bradykinin-induced prostaglandin formation from phosphatidylinositol turnover in Swiss 3T3 fibroblasts: evidence for G-protein regulation of phospholipase A2. Proc Natl Acad Sci U S A 84:6374-6378. CrossRef Medline

Chou CH, Lai SL, Chen CN, Lee PH, Peng FC, Kuo ML, Lai HS (2013) IL-6 regulates Mcl-1L expression through the JAK/PI3K/Akt/CREB signaling pathway in hepatocytes: implication of an anti-apoptotic role during liver regeneration. PLoS One 8:e66268. CrossRef Medline

Cox LJ, Hengst U, Gurskaya NG, Lukyanov KA, Jaffrey SR (2008) Intraaxonal translation and retrograde trafficking of CREB promotes neuronal survival. Nat Cell Biol 10:149-159. CrossRef Medline
Dalla Rosa L, da Silva AS, Gressler LT, Oliveira CB, Dambrs MG, Miletti LC, França RT, Lopes ST, Samara YN, da Veiga ML, Monteiro SG (2013) Cordycepin ( $3^{\prime}$-deoxyadenosine) pentostatin (deoxycoformycin) combination treatment of mice experimentally infected with Trypanosoma evansi. Parasitology 140:663-671. CrossRef Medline

Demetri GD, Chawla SP, Ray-Coquard I, Le Cesne A, Staddon AP, Milhem MM, Penel N, Riedel RF, Bui-Nguyen B, Cranmer LD, Reichardt P, Bompas E, Alcindor T, Rushing D, Song Y, Lee RM, Ebbinghaus S, Eid JE, Loewy JW, Haluska FG, et al. (2013) Results of an international randomized phase III trial of the mammalian target of rapamycin inhibitor ridaforolimus versus placebo to control metastatic sarcomas in patients after benefit from prior chemotherapy. J Clin Oncol 31:2485-2492. CrossRef Medline

Devor M (1999) Unexplained peculiarities of the dorsal root ganglion. Pain 6 [Suppl]:S27-S35. Medline

Dina OA, McCarter GC, de Coupade C, Levine JD (2003) Role of the sensory neuron cytoskeleton in second messenger signaling for inflammatory pain. Neuron 39:613-624. CrossRef Medline

Dina OA, Green PG, Levine JD (2008) Role of interleukin-6 in chronic muscle hyperalgesic priming. Neuroscience 152:521-525. CrossRef Medline

Dina OA, Khasar SG, Gear RW, Levine JD (2009) Activation of Gi induces mechanical hyperalgesia poststress or inflammation. Neuroscience 160: 501-507. CrossRef Medline

Eyre H, Baune BT (2012) Neuroplastic changes in depression: a role for the immune system. Psychoneuroendocrinology 37:1397-1416. CrossRef Medline

Fehrenbacher JC, Sun XX, Locke EE, Henry MA, Hargreaves KM (2009) Capsaicin-evoked iCGRP release from human dental pulp: a model system for the study of peripheral neuropeptide secretion in normal healthy tissue. Pain 144:253-261. CrossRef Medline

Ferrari LF, Bogen O, Levine JD (2010) Nociceptor subpopulations involved in hyperalgesic priming. Neuroscience 165:896-901. CrossRef Medline

Ferrari LF, Bogen O, Alessandri-Haber N, Levine E, Gear RW, Levine JD (2012) Transient decrease in nociceptor GRK2 expression produces long-term enhancement in inflammatory pain. Neuroscience 222:392403. CrossRef Medline

Ferrari LF, Levine E, Levine JD (2013a) Role of a novel nociceptor autocrine mechanism in chronic pain. Eur J Neurosci 37:1705-1713. CrossRef Medline

Ferrari LF, Bogen O, Levine JD (2013b) Role of nociceptor $\alpha$ CaMKII in transition from acute to chronic pain (hyperalgesic priming) in male and female rats. J Neurosci 33:11002-11011. CrossRef Medline

Ferrari LF, Bogen O, Chu C, Levine JD (2013c) Peripheral administration of translation inhibitors reverses increased hyperalgesia in a model of chronic pain in the rat. J Pain 14:731-738. CrossRef Medline

Ferrari LF, Bogen O, Levine JD (2014) Second messengers mediating the expression of neuroplasticity in a model of chronic pain in the rat. J Pain 15:312-320. CrossRef Medline

Fields RD, Eshete F, Stevens B, Itoh K (1997) Action potential-dependent regulation of gene expression: temporal specificity in $\mathrm{Ca}^{2+}$, cAMPresponsive element binding proteins, and mitogen-activated protein kinase signaling. J Neurosci 17:7252-7266. Medline

Foss FM (2000) Combination therapy with purine nucleoside analogs. Oncology (Williston Park) 14 [6 Suppl 2]:31-35. Medline

Herdegen T, Fiallos-Estrada CE, Schmid W, Bravo R, Zimmermann M (1992) The transcription factors c-JUN, JUN D and CREB, but not FOS and KROX-24, are differentially regulated in axotomized neurons following transection of rat sciatic nerve. Brain Res Mol Brain Res 14:155-165. CrossRef Medline

Hori T, Oka T, Hosoi M, Abe M, Oka K (2000) Hypothalamic mechanisms of pain modulatory actions of cytokines and prostaglandin E2. Ann N Y Acad Sci 917:106-120. CrossRef Medline

Johnston JB (2011) Mechanism of action of pentostatin and cladribine in hairy cell leukemia. Leuk Lymphoma 52 [Suppl 2]:43-45. CrossRef Medline

Joseph EK, Levine JD (2010) Hyperalgesic priming is restricted to isolectin B4-positive nociceptors. Neuroscience 169:431-435. CrossRef Medline

Joseph EK, Bogen O, Alessandri-Haber N, Levine JD (2007) PLC-beta 3 signals upstream of PKC epsilon in acute and chronic inflammatory hyperalgesia. Pain 132:67-73. CrossRef Medline

Joseph EK, Reichling DB, Levine JD (2010) Shared mechanisms for opioid tolerance and a transition to chronic pain. J Neurosci 30:4660-4666. CrossRef Medline

Kandel ER (2012) The molecular biology of memory: cAMP, PKA, CRE, CREB-1, CREB-2, and CPEB. Mol Brain 5:14. CrossRef Medline 
Khasar SG, Lin YH, Martin A, Dadgar J, McMahon T, Wang D, Hundle B, Aley KO, Isenberg W, McCarter G, Green PG, Hodge CW, Levine JD, Messing RO (1999) A novel nociceptor signaling pathway revealed in protein kinase C epsilon mutant mice. Neuron 24:253-260. CrossRef Medline

Khasar SG, Burkham J, Dina OA, Brown AS, Bogen O, Alessandri-Haber N, Green PG, Reichling DB, Levine JD (2008) Stress induces a switch of intracellular signaling in sensory neurons in a model of generalized pain. J Neurosci 28:5721-5730. CrossRef Medline

Kim J, Kwon JT, Kim HS, Han JH (2013) CREB and neuronal selection for memory trace. Front Neural Circuits 7:44. CrossRef Medline

Knöll B, Nordheim A (2009) Functional versatility of transcription factors in the nervous system: the SRF paradigm. Trends Neurosci 32:432-442. CrossRef Medline

Koç Y, McCaffrey R (1995) 2',3'-Dideoxyadenosine killing of TdT-positive cells is due to a trace contaminant. Leukemia 9:53-57. Medline

Kodama EN, McCaffrey RP, Yusa K, Mitsuya H (2000) Antileukemic activity and mechanism of action of cordycepin against terminal deoxynucleotidyl transferase-positive $(\mathrm{TdT}+)$ leukemic cells. Biochem Pharmacol 59: 273-281. CrossRef Medline

Lane-Ladd SB, Pineda J, Boundy VA, Pfeuffer T, Krupinski J, Aghajanian GK, Nestler EJ (1997) CREB (cAMP response element-binding protein) in the locus coeruleus: biochemical, physiological, and behavioral evidence for a role in opiate dependence. J Neurosci 17:7890-7901. Medline

Lee YS, Bailey CH, Kandel ER, Kaang BK (2008) Transcriptional regulation of longterm memory in the marine snail Aplysia. Mol Brain 1:3. CrossRef Medline

Lindgren CA, Newman ZL, Morford JJ, Ryan SB, Battani KA, Su Z (2013) Cyclooxygenase-2, prostaglandin E2 glycerol ester and nitric oxide are involved in muscarine-induced presynaptic enhancement at the vertebrate neuromuscular junction. J Physiol 591:4749-4764. CrossRef Medline

Ma CX, Suman VJ, Goetz M, Haluska P, Moynihan T, Nanda R, Olopade O, Pluard T, Guo Z, Chen HX, Erlichman C, Ellis MJ, Fleming GF (2013) A phase I trial of the IGF-1R antibody Cixutumumab in combination with temsirolimus in patients with metastatic breast cancer. Breast Cancer Res Treat 139:145-153. CrossRef Medline

Ma W (2010) Chronic prostaglandin E2 treatment induces the synthesis of the pain-related peptide substance $\mathrm{P}$ and calcitonin gene-related peptide in cultured sensory ganglion explants. J Neurochem 115:363-372. CrossRef Medline

Ma W, Zheng WH, Powell K, Jhamandas K, Quirion R (2001) Chronic morphine exposure increases the phosphorylation of MAP kinases and the transcription factor CREB in dorsal root ganglion neurons: an in vitro and in vivo study. Eur J Neurosci 14:1091-1104. CrossRef Medline

Ma W, Hatzis C, Eisenach JC (2003) Intrathecal injection of cAMP response element binding protein (CREB) antisense oligonucleotide attenuates tactile allodynia caused by partial sciatic nerve ligation. Brain Res 988:97104. CrossRef Medline

Maj-Hes A, Medioni J, Scotte F, Schmidinger M, Kramer G, Combe P, Gornadha Y, Elaidi R, Oudard S (2013) Rechallenge with mTOR inhibitors in metastatic renal cell carcinoma patients who progressed on previous mTOR inhibitor therapy. Oncology 85:8-13. CrossRef Medline

Mayr B, Montminy M (2001) Transcriptional regulation by the phosphorylationdependent factor CREB. Nat Rev Mol Cell Biol 2:599-609. CrossRef Medline

Mestre C, Pélissier T, Fialip J, Wilcox G, Eschalier A (1994) A method to perform direct transcutaneous intrathecal injection in rats. J Pharmacol Toxicol Methods 32:197-200. CrossRef Medline

Montminy M (1997) Transcriptional regulation by cyclic AMP. Annu Rev Biochem 66:807-822. CrossRef Medline

Montminy MR, Gonzalez GA, Yamamoto KK (1990) Regulation of cAMPinducible genes by CREB. Trends Neurosci 13:184-188. CrossRef Medline

O'Banion MK (2010) Prostaglandin E2 synthases in neurologic homeostasis and disease. Prostaglandins Other Lipid Mediat 91:113-117. CrossRef Medline

Ogawa E, Furusyo N, Kajiwara E, Takahashi K, Nomura H, Maruyama T, Tanabe Y, Satoh T, Nakamuta M, Kotoh K, Azuma K, Dohmen K, Shimoda S, Hayashi J (2013) Efficacy of pegylated interferon alpha-2b and ribavirin treatment on the risk of hepatocellular carcinoma in patients with chronic hepatitis C: a prospective, multicenter study. J Hepatol 58: 495-501. CrossRef Medline

Ohinata K, Yoshikawa M (2008) Central prostaglandins in food intake regulation. Nutrition 24:798-801. CrossRef Medline

Osaka T (2008) Prostaglandin E(2) fever mediated by inhibition of the GABAergic transmission in the region immediately adjacent to the orga- num vasculosum of the lamina terminalis. Pflugers Arch 456:837-846. CrossRef Medline

Ouseph AK, Khasar SG, Levine JD (1995) Multiple second messenger systems act sequentially to mediate rolipram-induced prolongation of prostaglandin E2-induced mechanical hyperalgesia in the rat. Neuroscience 64:769-776. CrossRef Medline

Parada CA, Yeh JJ, Reichling DB, Levine JD (2003a) Transient attenuation of protein kinase Cepsilon can terminate a chronic hyperalgesic state in the rat. Neuroscience 120:219-226. CrossRef Medline

Parada CA, Yeh JJ, Joseph EK, Levine JD (2003b) Tumor necrosis factor receptor type-1 in sensory neurons contributes to induction of chronic enhancement of inflammatory hyperalgesia in rat. Eur J Neurosci 17: 1847-1852. CrossRef Medline

Parada CA, Reichling DB, Levine JD (2005) Chronic hyperalgesic priming in the rat involves a novel interaction between cAMP and PKCepsilon second messenger pathways. Pain 113:185-190. CrossRef Medline

Quanhong Z, Ying X, Moxi C, Tao X, Jing W, Xin Z, Li W, Derong C, Xiaoli Z, Wei J (2012) Intrathecal PLC(beta3) oligodeoxynucleotides antisense potentiates acute morphine efficacy and attenuates chronic morphine tolerance. Brain Res 1472:38-44. CrossRef Medline

Reichling DB, Levine JD (2009) Critical role of nociceptor plasticity in chronic pain. Trends Neurosci 32:611-618. CrossRef Medline

Rottenberg ME, Masocha W, Ferella M, Petitto-Assis F, Goto H, Kristensson K, McCaffrey R, Wigzell H (2005) Treatment of African trypanosomiasis with cordycepin and adenosine deaminase inhibitors in a mouse model. J Infect Dis 192:1658-1665. CrossRef Medline

Sang N, Chen C (2006) Lipid signaling and synaptic plasticity. Neuroscientist 12:425-434. CrossRef Medline

Shaywitz AJ, Greenberg ME (1999) CREB: a stimulus-induced transcription factor activated by a diverse array of extracellular signals. Annu Rev Biochem 68:821-861. CrossRef Medline

Song MJ, Wang YQ, Wu GC (2009) Additive anti-hyperalgesia of electroacupuncture and intrathecal antisense oligodeoxynucleotide to interleukin-1 receptor type I on carrageenan-induced inflammatory pain in rats. Brain Res Bull 78:335341. CrossRef Medline

Su L, Wang C, Yu YH, Ren YY, Xie KL, Wang GL (2011) Role of TRPM8 in dorsal root ganglion in nerve injury-induced chronic pain. BMC Neurosci 12:120. CrossRef Medline

Sugar AM, McCaffrey RP (1998) Antifungal activity of 3'-deoxyadenosine (cordycepin). Antimicrob Agents Chemother 42:1424-1427. Medline

Sun JL, Xiao C, Lu B, Zhang J, Yuan XZ, Chen W, Yu LN, Zhang FJ, Chen G, Yan M (2013) CX3CL1/CX3CR1 regulates nerve injury-induced pain hypersensitivity through the ERK5 signaling pathway. J Neurosci Res 91: 545-553. CrossRef Medline

Taiwo YO, Levine JD (1989) Prostaglandin effects after elimination of indirect hyperalgesic mechanisms in the skin of the rat. Brain Res 492:397399. CrossRef Medline

Taiwo YO, Coderre TJ, Levine JD (1989) The contribution of training to sensitivity in the nociceptive paw-withdrawal test. Brain Res 487:148151. CrossRef Medline

Taiwo YO, Heller PH, Levine JD (1990) Characterization of distinct phospholipases mediating bradykinin and noradrenaline hyperalgesia. Neuroscience 39:523-531. CrossRef Medline

Teng FY, Tang BL (2006) Axonal regeneration in adult CNS neurons-signaling molecules and pathways. J Neurochem 96:1501-1508. CrossRef Medline

Tsai YJ, Lin LC, Tsai TH (2010) Pharmacokinetics of adenosine and cordycepin, a bioactive constituent of Cordyceps sinensis in rat. J Agric Food Chem 58:4638-4643. CrossRef Medline

Widnell KL, Self DW, Lane SB, Russell DS, Vaidya VA, Miserendino MJ, Rubin CS, Duman RS, Nestler EJ (1996) Regulation of CREB expression: in vivo evidence for a functional role in morphine action in the nucleus accumbens. J Pharmacol Exp Ther 276:306-315. Medline

Yang Q, Mattick JS, Orman MA, Nguyen TT, Ierapetritou MG, Berthiaume F, Androulakis IP (2012) Dynamics of hepatic gene expression profile in a rat cecal ligation and puncture model. J Surg Res 176:583-600. CrossRef Medline

Yoshikawa N, Nakamura K, Yamaguchi Y, Kagota S, Shinozuka K, Kunitomo M (2007) Reinforcement of antitumor effect of Cordyceps sinensis by $2^{\prime}$-deoxycoformycin, an adenosine deaminase inhibitor. In Vivo 21:291295. Medline 